Historic, Archive Document

Do not assume content reflects current scientific knowledge, policies, or practices. 


$$
\text { . }
$$


We are located $21 / 2$ miles South of the Center of Poughkeepsie, on the Albany Post Road, Route 9E., adjoining the Dutchess Golf \& Country Club.

\section{Telephone:} POUGHKEEPSIE

\section{3}

Trial Gardens Open Daily

Except Sunday. 


\section{Well-known and little-known Plants as observed and photographed by P. J. van Melle}

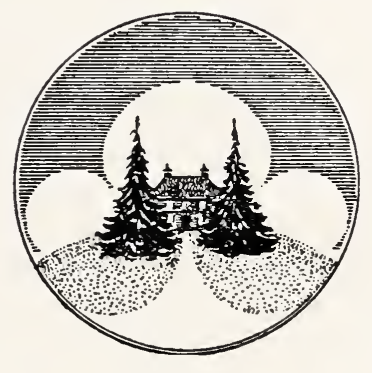

Grown and Offered by

The Poughkeepsie Nursery Company, Inc.

Poughkeepsie, N. Y. 


\section{A Message-Strictly Business}

Nothing so well insures a satisfactory deal as does personal inspection of materials at the nursery.

We maintain an extensive trial garden, for the convenience of our customers, where hundreds of additional species and varieties of plants may be seen. This garden is open for visitors every week day. Amateurs in quest of rare odds and ends will always find plants to interest them.

Those who are making planting lists for rock gardens may find it worth while to make notes in our garden and to inspect our stocks. Things will be found here which may well be added to planting lists in favor of other plants selected from catalogs.

Nearly all our plants are grown in three-inch pots. Some of the tinier plants, like Sedum dasyphyllum, Sempervivum fauconnetti, etc., are from $2 \frac{1}{2}$-inch pots. A few items, like some of the Saxifragas, are dug from the frames or garden. Shrubs are dug in the nursery and evergreens will be sent balled-and-burlapped.

We send out only such plants as can be expected to establish themselves in gardens. No stock will be sent out which is too small or too weak to be used in the rock garden.

Pot-grown plants are ideal units of rock garden material. They may be shipped, whenever ready, at convenient times and will not suffer the severe check to which field-grown plants are subjected in shipping and transplanting. Please remember that many rock plants are small or slow-growing or difficult things and that one is not to expect, generally, as showy clumps of these as one would of Coreopsis or Shasta Daisies.

Plants will be packed with the utmost care. Should any errors occur in the filling of orders, please advise us promptly and we shall correct them at once.

Orders are accepted subject to damage to our stock or losses through causes beyond our control. Shipments travel at the purchaser's risk. Our responsibility for shipments ceases when they have been delivered to the transportation Company. 
Shipments. How and when. We will ship plants promptly or on dates specified, in so far as they are ready for shipment. Unfilled balances of orders will be shipped when the plants are ready for delivery. Advance notice of such shipments will be sent. Shipments will go out with transportation charges collect.

Motor delivery is often advisable and can be arranged for at cost.

Names and descriptions of Plants. Every effort is directed here toward having all plants correctly named. Instances in which the name is not certain are so indicated in this catalog. Descriptions have been made from observation in our trial garden.

Terms, rates and discounts. Purchasers unknown to us will please remit with their orders. Prices are net, cash.

The following quantity discounts will be allowed: Five percent on all orders amounting to from fifty to one hundred dollars. Ten percent on all orders over one hundred dollars.

The following rates are applied:

The five-rate applies to from three to nine plants of any one listing.

The ten-rate applies to from ten to twenty-four plants of any one listing.

The 100 rate applies to twenty-five or more plants of any one listing.

For single plants or two-of-a-kind, add 5 cents a-piece to the five-rate.

A convenient Order Blank is provided with this catalog.

Please read the above information carefully. Orders are accepted only upon the above terms and conditions.

\section{POUGHKEEPSIE NURSERY COMPANY, INC.}

$$
\text { Poughkeepsie, N. Y. }
$$

P. O. Box 278 


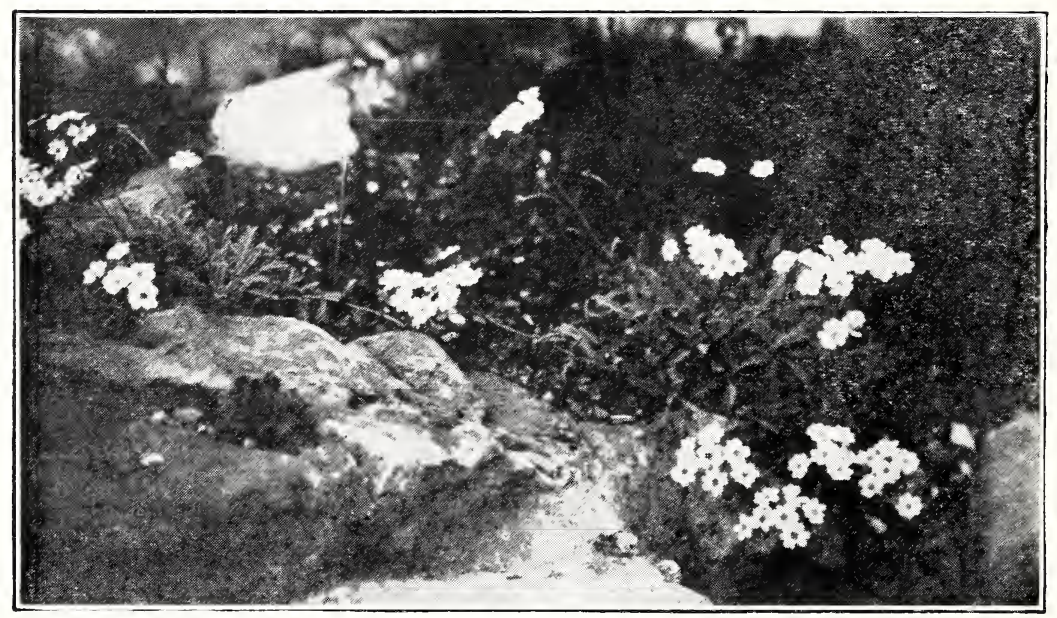

Achillea argentea.

\section{ROCK-GARDENS IN THE LOWLAND MANNER}

The joys of rock gardening are varied and arrived at by different roads. The lover of alpine scenery may find his joy in the approximation, in a garden, of alpine conditions and in the gathering of plants from high altitudes. That is a very fine conception of rock gardening, but one which the average gardener finds it difficult to realize in harmony with the aspects of his home-grounds. It is the phase reserve for the exceptional place which affords suitable scenery. It loses its merit when it lacks the background of harmonious scenery or of genuine enthusiasm on the part of the owner for alpine effects.

The gardener in the lower lands or hill-country will probably derive more joy from a less orthodox conception than that of "alpine gardening". To him the rock garden is most happily that bit of naturalistic garden in which he may gather all manners of wildlings, native or exotic, that will blend with such naturalistic rock groupings as local wild scenery may inspire and the place may accomodate harmoniously.

To him the rock garden is not necessarily a mountain scene reduced to garden limits. It is not any separate garden unit devoted to rocks or ledges, however well-made, but rather all such bits of rock-scenery as may occur or be made to occur in a harmonious, nature-like manner in the general scheme of his grounds. These rock-groups may be bold, on a hill-side, or of finer, more amenable character where they approach a path or project into the lawn. 
They are not rock gardens in the sense that they have definite, garden-limits. They are vaguely defined groups of rocks, incidental to the larger scheme.

From this viewpoint, then, rock gardening is simply a phase of naturalistic gardening that deals with rock groups. The composition of the rock groups will then naturally derive its inspiration from natural local rock formations and the selection of plant materials may well be made with deference to native foliage and flower effects, with greater freedom of treatment where the rocks project out from the naturalistic picture into the lawn.

The increasing interest in rock gardening results at the present time perhaps too much in the creation of separate garden-units devoted to miniature mountain-scenes. We need to remember that in the lowlands or in the modest hills we have very lovely inspiration at hand in nature's own disposition of rocks all through the country-side. Our rock gardens should not be of garden-like outline; they should be sketchy and definitely related to the larger aspects of our grounds.

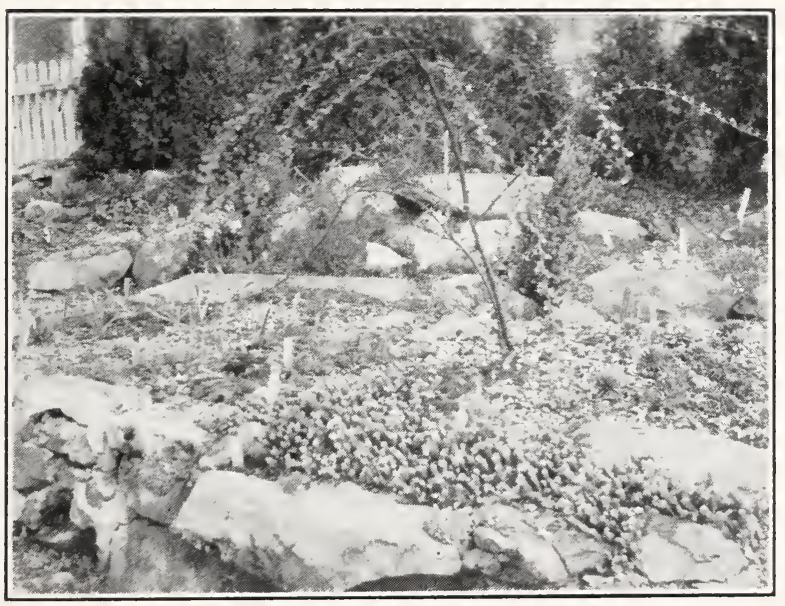

Sedum rupestre,-a small form. One of the most decorative Sedum species. 


\section{ROCK PLANTS \\ As I Know Them}

By Peter J. van Melle

ACAENA cylindrostachys. A quick-growing, prostrate plant which makes rather coarse rambles of bright-green, small, rose-like foliage. Suitable as a cover for poorish, porous soil, but not a choice plant.

buchanani is a dainty, slower groundcover for light, porous soil, in sun or light shade. It makes lovely, clear gray, fine, tiny rose-leaves and forms rather slowly into sizeable patches, more or less bronzy gray when used in shaded places. A good cover for small bulbs. Very pretty.

ACHILLEA. Yarrow. The following dwarf Yarrows are for sunny, dry, poorish soils. Most of them are showy in bloom and all have value as cushions in the garden.

ageratifolia. One of the best. Tufts of gray foliage, finely toothed and large, showy heads of white, small daisies, on 8 -inch stems.

argentea is very like the preceding in flower but has more striking, clear silver, beautifully cut foliage. A very choice plant.

nana is not much in flower but makes rather neat, dullgreen cushions of somewhat woolly foliage. Better keep the flower stems cut out.

tomentosa. Woolly Yarrow. Very pretty cushoins, 1 inch high, of green, woolly foliage, from which rise 6 to 8 -inch stems, in June, bearing brilliant yellow flowerheads.

tomentosa alba. Mounds of gray foliage, 4 inches high, with white flowerheads, in June, on 6 to 8 -inch stems. Not so showy in flower as some others, but quite pretty when massed.

AETHIONEMA. Stonecress. We offer a good strain of pink seedlings. They are lovely plants for light, welldrained, sunny spots, topped in May with heads of soft pink flowers. The plants are quite woody and shrubby in a small way. The foliage is really beautiful-steelgray. To bring this out to advantage, cut the flowerstems directly after blooming. 
AJUGA genevensis. True genevensis, such as we offer,

is a fine, foot-high spire of clear blue, in May and June.

The plant makes no runners, does not creep and seeds itself freely in the garden. It is not a coarse plant like reptans. It has gray-green, rough foliage and thrives in any reasonable soil, best in light shade.

ALCHEMILLA alpina. Lady's Mantle. A lovely plant. It makes tufts or mats of decorative, long-stalked, palmately divided leaves, shiny green above and with a lovely, silky reverse. Not a showy plant, but a charming thing to tuck away here and there in a dry, light, sunny spot. The flowers are insignificant and are as well kept cut out.

ALYSSUM rostratum. A broad, quite shrubby plant with flat, greenish-yellow flowerheads in summer. These flowers are not particularly pretty, but quite effective. Use it in poor, dry spots and not a great deal of it.

saxatyle compactum. A compact form of the familiar Golden Basket.

montanum is quite pretty and lasts long in bloom. Mats of bright gray foliage, 2 inches high, topped in spring with heads of yellow flowers, up to 5 inches high. The plant is somewhat shrubby.

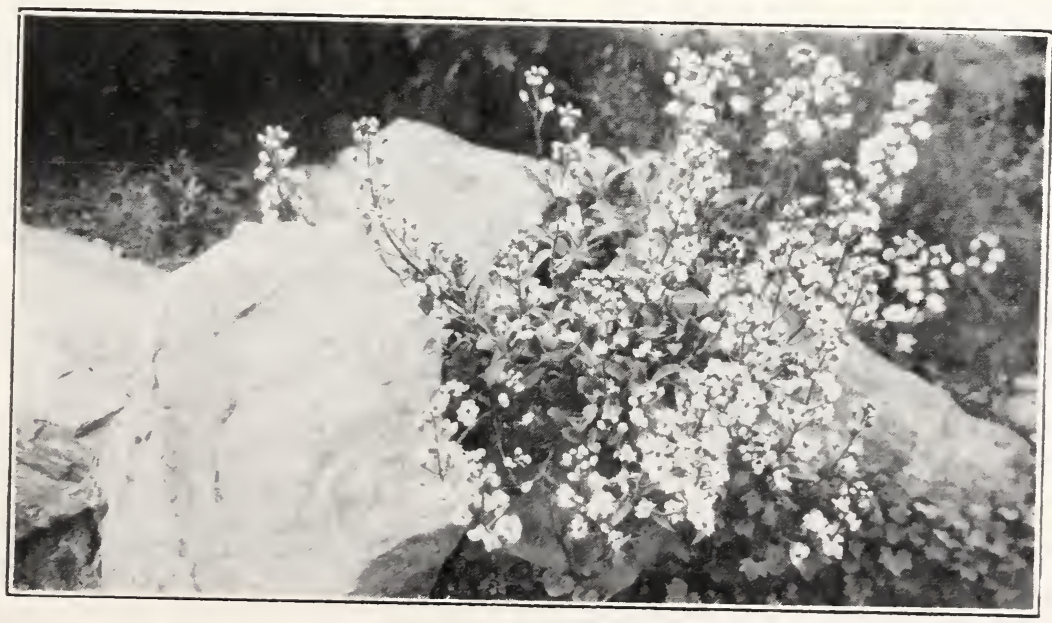




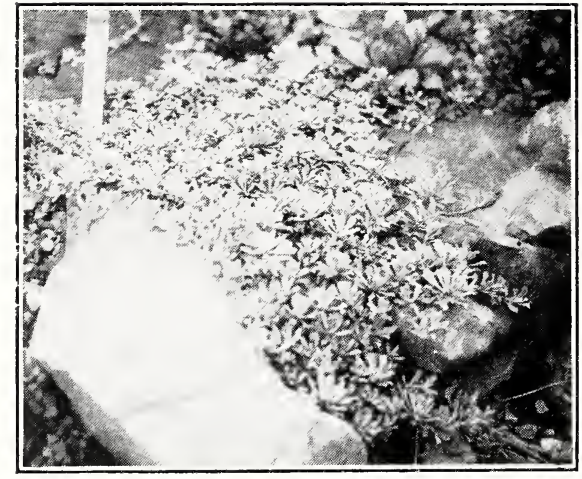

A site sloping toward the North, with no heavy shade overhead is to be preferred for the rock garden.

The shade of a small tree or narrow evergreen, here and there, protects many plants from the hottest sunshine for an hour or two each day, as it moves a round with the sun.

Antennaria neodioica makes a

silvery-gray mat of fine texture, in poorish, light soil.

ANCHUSA myosotidiflora furnishes the shadier spots in the garden with robust sprays of clearest blue forget-menots in the spring and with 10 to 12-inch clumps of long-stalked, large, heart-shaped, rough, flannelly leaves in summer. A very valuable, dependable perennial plant, which, moreover, seeds itself freely in the garden.

ANDROSACE carnea brigantiaca is a choice little tuft of grassy foliage, $3 / 4$ inch high and lovely little white flowerheads on $2 \frac{1}{2}$-inch stems, in April. For welldrained, open spots, in the best of company.

sarmentosa. This very lovely plant makes mats of gray-green, $1 \frac{1}{2}$ to 2 -inch rosettes from which rise, in May, little 2 to $21 / 2$-inch stems, topped with pink, verbena-like flowerheads. From the rosettes radiate numerous thready, reddish runners, each ending in a new rosette which roots where it comes to rest. Toward winter the rosettes become more compact and woollier. A choice little thing which should be planted freely in well-drained, sunny or lightly shaded, dry places.

sarmentosa chumbyi is a little more silvery-gray of leaf and a little deeper in flower but not markedly better than the type.

sarmentosa watkinsi is another choice, small form.

lactiflora (coronapifolia). A charming little annual which, from a small basal rosette, sends up numerous erect stems with umbels of tiny, white flowers. Use it in a light, porous soil, in open places. It seeds itself freely. We offer only the young seedlings, taken from the garden. These are quite small, but will establish themselves readily. Spring delivery only. 
ANTENNARIA neodioica. A very valuable, tight-mat-

ting, gray blanket of fine texture, for light, sunny soils. It is a small-leaved form of Cat's Ear, which covers the ground or drapes itself over the rocks. The flowers are of no merit and are better kept cut, in spring.

rhodantha. This is a little larger-leaved form which will create the same type of mat, though not quite as dense as neodioica. The pink flower buds are pretty but the open flowers are disappointing. Better cut the flower stems as soon as the flowers open.

ANTHERICUM liiastrum majus. St. Bruno's Lily. Beauciful, pure-white, lily-like flowers on 12 to 15-inch stems, in June. Of easy culture in any light loam.

AQUILEGIA alpina. Depending on soil, it will vary from one to two feet in height. Large flowers of a rich, strong blue. It is a beautiful and distinct thing and does well in any light so:l, in sun or light shade.

coerulea. The Rocky Mountain Columbine. A beautiful Columbine of graceful habit, with lavender-blue flowers, long-spurred and with creamy-white centers.

flabellata nana. This small, gray-leaved, early flowering Columbine has flowers of a peculiar, waxy appearance, on 8 inch stems, in April or May. A charming thing, varying in color from white to pale lilac-blue.

ARABIS albida. The single white Rock Cress.

albida flore pleno. This is quite distinct from the single form in flowering qualities. It hears strong spikes of large, double flowers, which are most decorative and have cut-flower value. This plant thrives and blooms well See Cut Page either in sunny or lightly shaded places.

kellereri is a little mat of tiny gray rosettes, scarce $1 / 4$ inch h:gh, with tiny white flower heads in April. A very choice little plant for sunny, gritty soil.

molis is a first-rate, quick-spreading ground-cover. It makes solid mats of deep-green, shiny foliage. It is not averse to moisture and sends up thin, wiry siems, 10 to 12 inches high, with white flower heads in April. This is one of the most satisfactory cover plants for larger areas.

ARENARIA verna caespitosa or Sagina subulata makes large, mossy sods, not over $1 / 4$ inch high, of a rich, grassgreen. These sods are sprinkled in mid-summer with small, white, starry flowers. This plant is best kept away from brightest sunshine. It suffers from sunburn in South exposures. A very fine paving plant. 
Page ARMERIA cephalotes is a robust, grass-leaved Thrift

10 with deep rose flowers on 8 to 9 inch stems in May.

cupluroides might be described as a small, refined version of formosa. It makes small loose tufts of blue-green, broadened grass-leaves, from which rise, in June, 7-inch stems, topped with white flowers in small heads. A very graceful thing and rare.

laucheana makes broad sods of grassy foliage, $1 \frac{1}{2}$ inch high, with deep rose flowerheads, more continuously than maritima.

maritima is the old-time Thrift, a favored edging plant in olden days. The pale-rose flowerheads are quite as lovely as those of laucheana.

maritima alba is a dainty white-flowered form, a much more difficult plant to keep than the type. It makes weakly, small sods, which should be kept away from brilliant sun. Six Hills Hybrid is a striking, most welcome variation from maritima. It makes compact tufts of stiff, deep green foliage, from which rise, throughout the summer, shortstemmed, pale rose, large flower heads. A very fine thing.

ASPERULA odorata, indispensable herb in the days of May-bowls, is no less valuable to-day for its charming, tumbling masses of foliage in shady spots. It spreads great sheets, topped in May with white forget-me-not flowers. The young foliage, when crushed or dried, smells delightly of new-mown hay. It is the German Waldmeister, -Lord of the Woods.

Cornus canadensis.

Bunchberry.

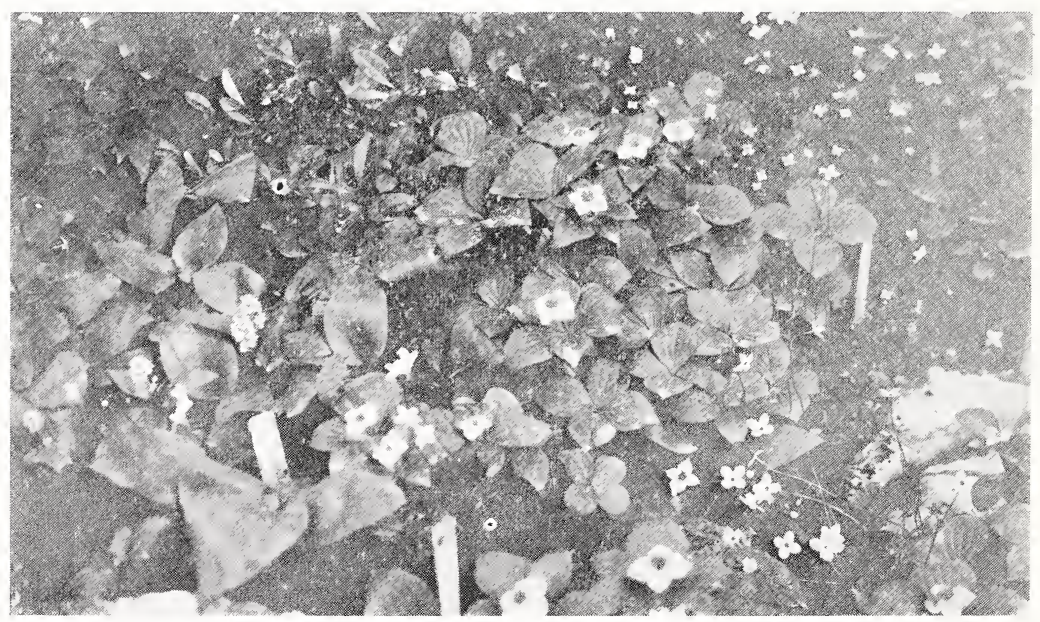




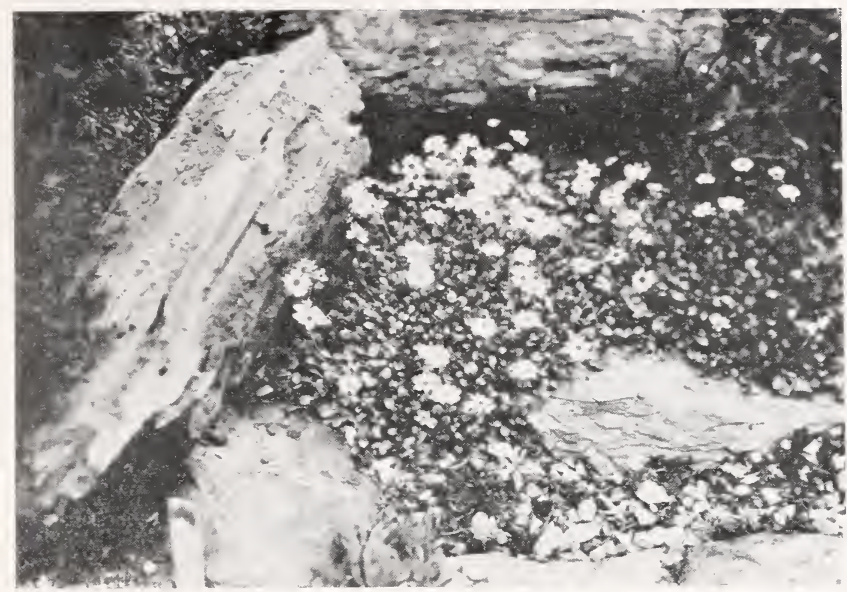

Bellium

minutum.

ASTER subcaoeruleus. A most beautiful alpine Aster, after the style of alpinus,-more beautiful and perhaps more difficult to keep. Large and brilliant flowers, mauve, with vellow center. 12 to 15 inches high, in May or early June. Does best in well-drained, chippy soil.

Farreri. A very fine species after the general style of alpinus, rather robust, with mauve rays and yellow centers. May.

Mauve Cushion. A very late-flowering Japanese. It makes solid mounds, with small, mauve flowers in great abundance, in October. It varies in habit according to the soil in which it grows. It makes a nice small plant in very poor soil, sunny and well-drained. In richer soil it becomes a perfect fall-bedding plant.

AUBRETIA, seedlings. We offer mixed seedlings in a wide range of shades from light rose to deep-purple. Aubretia should be used freely in the Rock Garden. They make pretty, trailing mats, covered in April or May with a most lovely sheet of soft color. They may be planted in shallow, poorish soil and like to trail over the rocks. They furnish much of the best spring color in the Rock Garden.

BELLIUM minutum or rotundifolium is a most charming and ingratiating miniature of the English Daisy, which makes lusty patches of bright green foliage, $3 / 4$ inch high, in sunny, well-drained, chippy, light soil. It sends up an endless show of $1 \frac{1}{2}$ inch stems with tiny Bellis flowers. A lovely plant and worth having. 


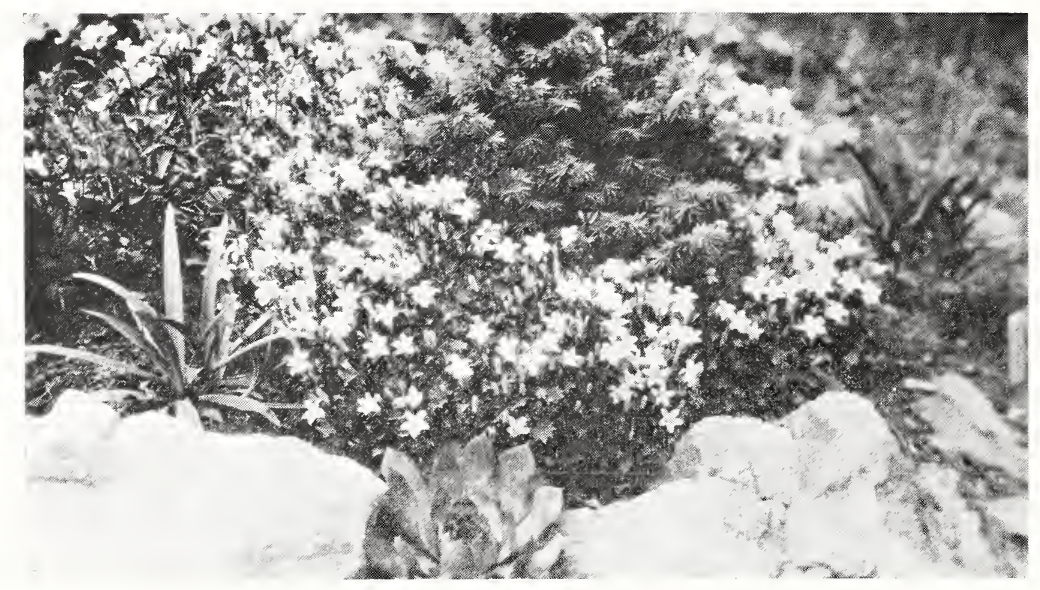

Campula portenschlageana (C. muralis).

BERBERIS Julianae. A pretty evergreen shrub for the Rock Garden. It grows up to about $4 \mathrm{ft}$. Long, narrow, glossy green foliage and prominent, long thorns. Best used in lightly shaded spots.

verruculosa. Perhaps the choicest of the evergreen Barberries. It makes a small, compact bush with deep green, glossy, somewhat twisted foliage, which turns winered in winter. 'The reverse of the leaves is silver-gray. A very lovely little shrub, easy to grow.

buxifolia nana is a tiny thing, about 6 inches high, not quite evergreen, but here retaining its foliage till midwinter. A compact bush with oval, deep green leaves which turn reddish in the fall. Hardy and easy to grow.

buxifolia pygmea is a still more compact form with tiny, round leaves. Thornless, and a most attractive-looking little shrub in the rock garden. 6 inches.

BRUCKENTHALIA spiculifolia. This is a lovely little Heather which forms broad patches, about 4 inches high, with rose-pink flowers in June or July. A choice and rare thing. It will thrive in soil that suits Heather-a sandy peat. For best effect, it should be used in masses.

CAMPANULA Bellardi (Campanula pusilla) is a charming little Bell-flower, which makes broad little clumps, with wiry stems rising from 4 to 6 inches high in July. A lovely thing, but not very permanent. It wants a wellPage drained, gritty soil in not too brilliant sunshine. Light shade is desirable. Light blue, small bells. 
portenschlageana ( $\mathrm{C}$ muralis) cheers the garden in June with tidy clumps of foliage, 3 to $t$ inches high and a great abundance of violet-blue bells A most lovely and quite permanent plant. Sun or light shade, in any reasonable soil.

raddiana makes graceful, airy foliage and flopping flower-stems, up to 10 inches long, topped with violet-blue bells. A very pretty and graceful thing, in June.

scheuchzeri is just a fine form of our Harebell.

CERASTIUM tomentosum is the popular, gray-leaved, white-flowered plant, so suitable for wall-gardening and for use in sunny, poorish soils. A very common and very beautiful thing.

thomassi (soleiroli) makes a tight little mat, $1 / 2$-inch high, of grey-green foliage and sends up 4 -inch flower stems with white flowers.

CHAMAECYPARIS obtusa compacta. This is a dwarf Hinoki Cypress, with which the Japanese do wonders in their rock gardens. They are oddly, irregularly shaped and always seem to fit in well. The foliage is dark green and does not discolor. They are dwarf and slow-growing.

CHRYSANTHEMUM arcticum makes rather rampant mats of dark green, glossy foliage, from which rise handsome white daisies, on 8 -inch stems, in late fall. A very fine plant for late fall effects. It wants room.

Thamaecyparis obtusa compacta, one of those beautiful, dwarf forms of Himoki Cypress.

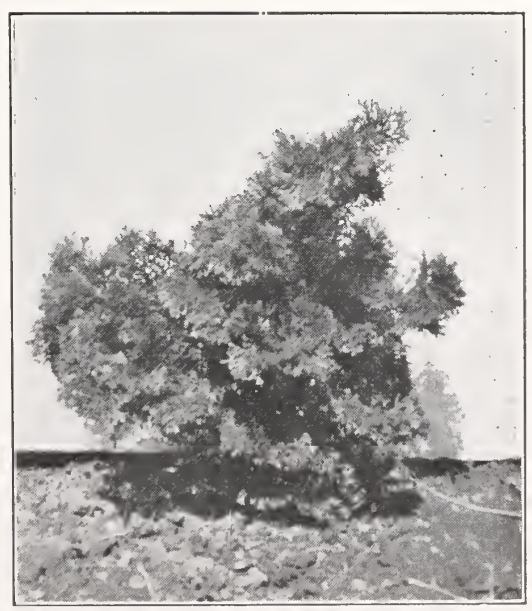


CORNUS canadensis, the Bunchberry of Northern woods, makes very lovely patches in the wilder parts of the garden.

\section{See \\ Illustrations \\ Page \\ 10}

It wants an acid soil, not too damp nor too heavily shaded. Once established, it will treat you to its little Dogwood flowers and red berries from year to year. It flowers and fruits well in our garden. We offer potted plants, which should establish themselves more easily than collected clumps.

CORYDALIS cheilanthifolia is a decorative plant for shady corners with finely cut, almost fern-like foliage and bright-yellow flowers in June.

bulbosa is an early flowering, bulbous species which cheers the garden in April. It makes light, airy, fine foliage clumps about 7 inches high, with sprays of pink flowers well above it. It goes dormant soon after flowering and is not heard from again till the following spring. It is for shady places and it seeds itself freely. We offer them for spring delivery only.

lutea is a very fine plant. Depending on soil, it grows from 10 inches to $1 \frac{1}{2}$ feet high, into massive clumps of gray-green finery, above which there is, all summer long, a fine display of yellow flowerheads. It wants a light, not too rich soil, in light or heavy shade.

COTONEASTER microphylla is a pretty, spreading, evergreen shrub of small proportions which will be found very useful and decorative in some sunny, well-drained place in the rock garden. Its white blossoms, in May, its red berries in the fall and the shiny, small leaves at all times entitle this little shrub to a choice place in the larger rock gardens.

horizonta?is perpusilla. A variety of horizontalis of slower growth, smaller leaves, smaller and more numerous red berries. A spreading shrub of finer texture than the type.

COTULA squallida (Leptinella s.) A fine little groundcover for dampsh, shady places. It makes loose mats, about 2 inches high, of finely cut foliage, like a small fern or yarrow. It does best if planted at the edge of a shaded pool.

DIANTHUS alpinus. This makes tight mats, scarce $1 / 2-$ inch high, of bright green foliage, from which rise short stems, topped with large, rose-pink flowers, in early June. 
A very choice and delightful plant for open, sunny loca-

tions. It wants a well-drained, gritty soil with lots of lime, which should be added from time to time.

alpinus $\mathrm{X}$ superbus. A magnificent hybrid. It has the low, tufted habit of alpinus, with larger, more robust foliage. From it rise 4 to 6 -inch stems with large, flat cartwheels of rose pink, with a beautiful fringed edge. A beautiful and rare thing.

caesius arvernensis. This lovely form of Cheddar pink makes large mats of short, gray foliage, little more than an inch high. It blazes forth, in early June, with a great show of bright rose-pink flowers, about $2 \frac{\mathrm{I}}{2}$ to 3 inches h:gh. We offer plants grown from divisions, of a uniform shade.

knappi is a sprawling, long-stemmed pink from the Balkan States, quite hardy and permanent, which blooms from early July till fall with rather cheerful though not brilliant heads of yellow flowers, clustered after the style of Sweet IVilliams.

DODECATHEON radicatum. The Shooting Stars are most graceful things in the garden. This species grows about a foot h:gh, bears pale lilac-rose flowers and is not as robust nor as tall as media. It should be set in a lightly shaded, rich loam and rather damp. The flowers appear in May. The plant usually goes dormant in midsummer.

Dianthus alpinus.

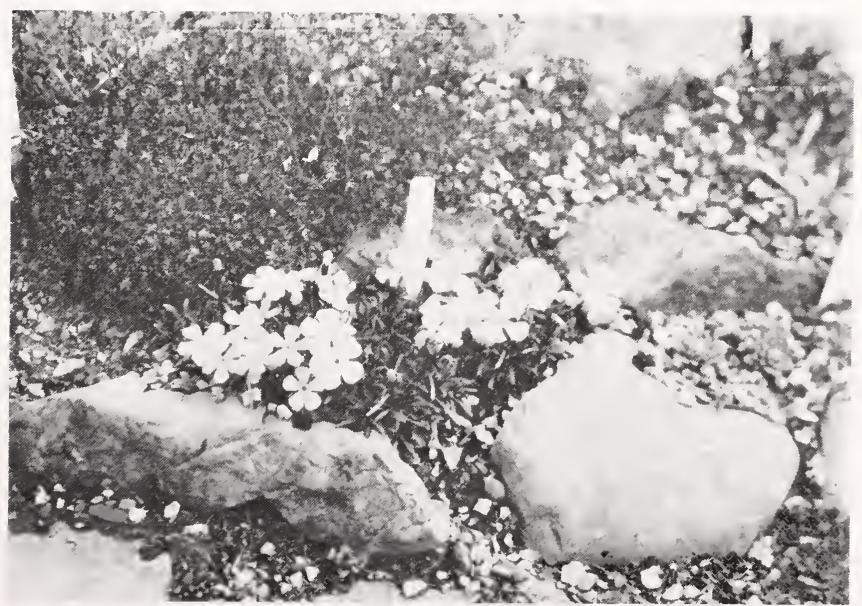


Page DRABA androsace (flatnitzensis). A tight-matting plant, 16 with crowded rosettes of bright green, shiny foliage. It bears white flower heads in spring, like tiny Arabis-heads, but these are not particularly showy, nor numerous. The value of the plant is in its beautiful, close, 1-inch-high cushions of foliage. It wants a gritty, sandy soil and an open location.

kutschyi is exactly like D. aizoides, except that it is a little larger and showier than that very tiny species. It makes small, bright green, hairy rosettes or huddles of rosettes, from which rise, as soon as spring comes in, 2-inch stems topped with brilliant yellow flowerheads. A very choice little thing for the rock work,-for deep crevices or joints of stones.

olympica (bruniaefolia) makes dense cushions of dark green, small rosettes, which are very effective and very brilliant with their yellow flowerheads in early spring.

repens departs from the rosetted style of the preceding species and is a small, loose, leafy, trailing mat of light green foliage, $3 / 4$ inch high. From this rises, in early spring, a veritable forest of 2 to 4-inch flower stems, topped with brilliant yellow heads. A most lovely and showy thing, which will often throw in a second, tho' lesser burst of flower in the fall. It is not a rampant spreader and we recommend it as a very fine plant for the rock garden.

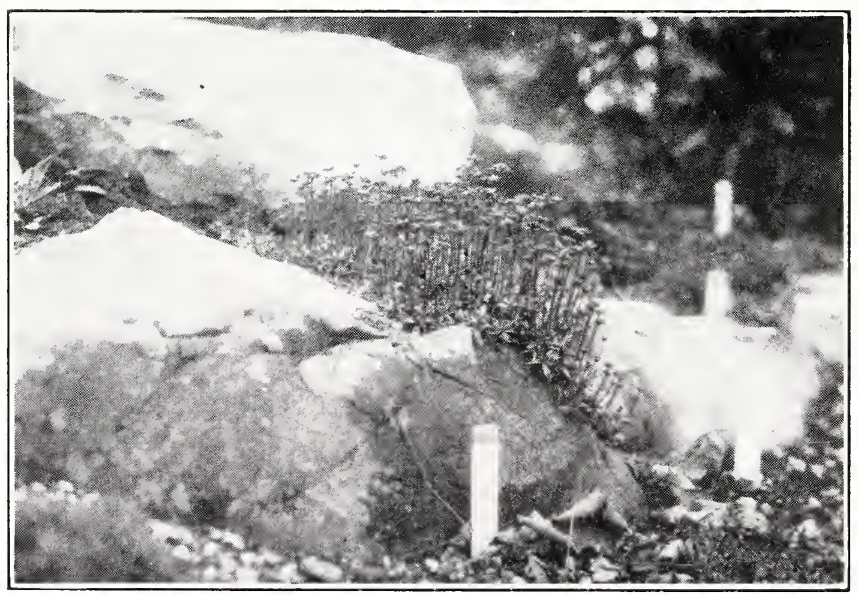

Draba repens is a lovely, bright-yellow little thing for early spring. 


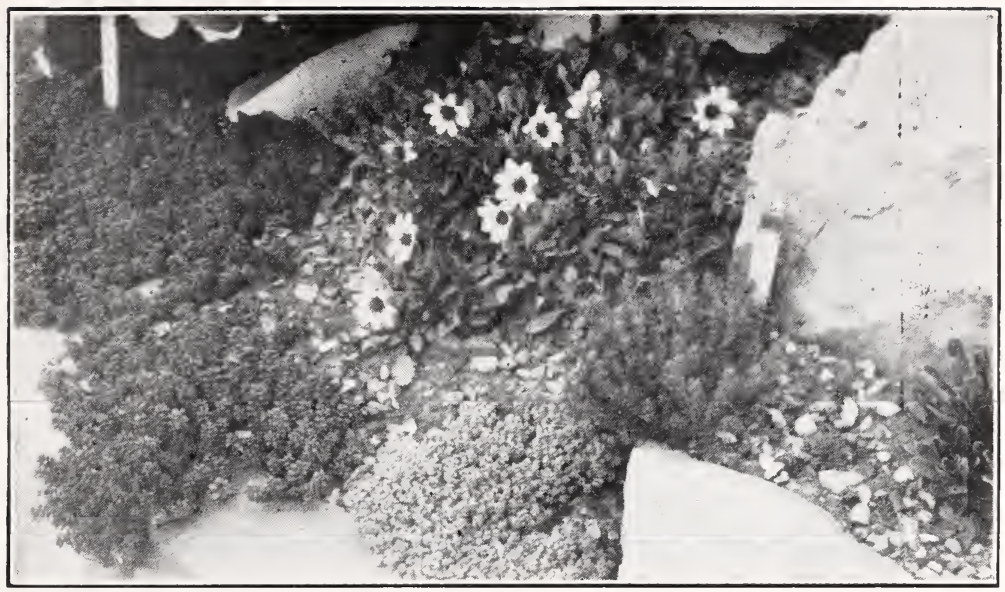

Left, a Compact form of Sedum album, top, Dryas Sundermanni, below, Sedum dasyphyllum, right Sedum stribrnyi.

DRYAS octopetale makes a loose mat of evergreen foliage, from which spring, in June, large, creamy blossoms like giant, wide-open Anemones. 'These flowers are followed by fluffy, silken seed-plumes. Dryas will grow in any well-drained, open or lightly shaded soil. They do not always transplant easily and are best moved in August, when the runners send their new, white, fleshy roots into the ground.

Sundermanni is a hybrid, with larger flowers with more of a golden glint. A robust and, as we find it, a somewhat taller plant.

EPILOBIUM nummularifolium. A tiny, pretty groundcover, not over $\mathrm{I} / 4$ inch high, with minute, rounded, bronze-green leaves. It makes a good cover plant for small bulbs and is so small that it will not easily choke any frail, choice thing in the garden. It grows like a little weed in any light, well-drained, open soil.

ERIGERON mesa grande speciosus. This is an exceptionally fine Erigeron, which makes stems up to $2 \frac{1}{2}$ feet high, topped with flowers which one would not tell readily from the best of Aster alpinus, except that they are of extraordinary fine quality and carried most gracefully aloft. If the flower stems are cut after blooming, the plant will make a neat, modest tuft of 3-inch high, green foliage. This plant will do well in any open, reasonable and well-drained soil. 


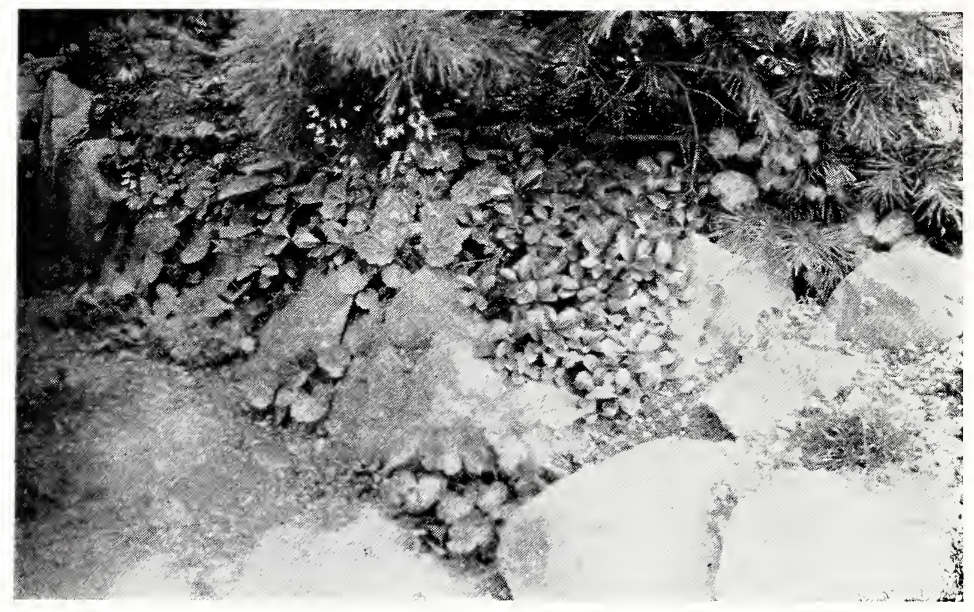

Gaultheria procumbens (Wintergreen), tucked away under an evergreen, where it has been joined by a bit of Saxifraga sarmentosa, whici likes it cool and moist.

ERINUS alpinus makes neat little tufts of foliage, scarce an inch high, from which rise 3 to 4 -inch stems in May or June, with rose-carmine flowers. A pretty alpine, for well-drained soils, best kept from too brilliant sun and best divided from time to time. Older clumps seem not to winter very well.

ERYSIMUM auranthiacum. A neat, small Erysimum with orange flowers, much to be preferred in the garden to the rather rank and weedy, yellow E. pulchellum. A really lovely plant, which makes neat, modest clumps of bright green foliage after the flowers have been cut away. Our plants were raised from cuttings.

EUONYMUS radicans minima (Euonymus kewensis.) This is a lovely, tiny-leaved, dark-green trailer which makes beautiful patches in the rock garden. It spreads in width to some extent, but seems as well to mound its foliage up, until the old, established clumps have some height. It succeeds almost anywhere, but best in a dampish, somewhat shady corner.

GALAX aphylla is a decorative woodland plant from the South with leathery, round leaves shaped like Violetleaves. This foliage turns maroon red toward fall. It Page sends up tall spiry spikes in June, with close-set, white flowers. It wants an acid soil and woodland conditions. 
will thrive very readily in any shaded spot with an acid, woodland soil. It makes a beautiful, matting, evergreen patch, 2 or 3 inches high, with glossy, leathery, evergreen foliage. The tips of the young growth are wine-red. Drooping, white-waxy flowers and bright red berries. These persist throughout winter and spring. We offer potted plants, which should be easily established.

GENISTA sagittalis. Makes a broad mat of trailing growth from which rise 6-inch high, erect branches, topped in June with yellow flowers. The foliage is light, bright green. It is an interesting and useful shrub for poor, hot soils. Showy in bloom.

GENTIANA acaulis (G. gentianella). A low, tufted plant, 1 inch high, with large wide-open cups of clearest blue in May. It is the most beautiful of Gentians and should have a deep, rich soil which does not lack moisture. An open location, as cool as can be found, suits the plant best.

GERANIUM pyzlowianum makes a loose, thin spread of prettily divided foliage, from which rise, in June, large clear-rose flowers, on 4 to 5 inch stems. A most graceful thing and rare.

GEUM montanum is a small rosette of rough, typical Geum leaves, with 5-inch stems, bearing large, cup-shaped, clearyellow flowers in April. It is perhaps the best of the Geums for the rock garden.

triflorum is a native which has dark green, rough foliage and sends up sprays of rose-colored flowers in earliest spring, on reddish, hairy stems. These flowers are followed by long, fluffy, silky seed-plumes.

GLOBULARIA cordifolia makes compact, low, slowgrowing mats, $1 \frac{1}{2}$ inches high, of evergreen foliage in small rosettes and bears the typical, blue flowerheads of its kind on very short stems.

nudicaule makes a looser mat, not quite so dwarf, with woody stems and carries its blue flowerballs on 5 to 7 inch stalks. It is a pretty and effective plant. If left undisturbed it will form quite large mats. All these Globularias do best in a gritty, humus soil, in light shade.

trichosantha is quite like nudicaule, except that the flower stems bear a few small leaves.

HEDERA minima is a small, dwarf, deep green ivy which does not climb, but which makes a very pretty effect when tucked in beside a large rock in a shady corner. 
Page HELIANTHEMUM. Rock Rose. We offer seedling 20 plants in mixed shades. White, yellow, pink and buff. These are not sold in separate colors. They will make large, evergreen mounds, which in June bear their lovely profusion of single, rose-like flowers. The plants should be sheared back after flowering time. They are decidedly of a shrubby nature.

HERNIARIA glabra is a bright green, rapid spreading trailer, not over $1 / 2$ inch high. It makes a very good paving plant. It needs no care, and seeds itself to some extent.

HEUCHERA brizoides. Plui de Feu. A showy, rose-red Coral Bell which blooms all summer.

Sanglant. Brilliant red flowers. A very showy variety. Virginal. A pure white Coral Bell, fine for interplanting with the red.

HOUSTONIA coerulea. Bluet. Quaker Lady. This lovely little wild plant should be allowed to seed itself in every rock garden. Outside of the sprinkling of little azure stars in May, one scarcely notices its presence in the garden. It is happiest in the more shaded spots. We offer potted tufts of young seedlings. The plant itself is not very permanent, but it provides each year an abundant crop of new seedlings.

serpyllifolia is exactly like coerulea in flowering qualities but it is a more permanently perennial plant, forming dense, creeping mats of very fine, grayish foliage.

Houstonia We grow it in light shade.

coerulea.

Quaker

Lady.

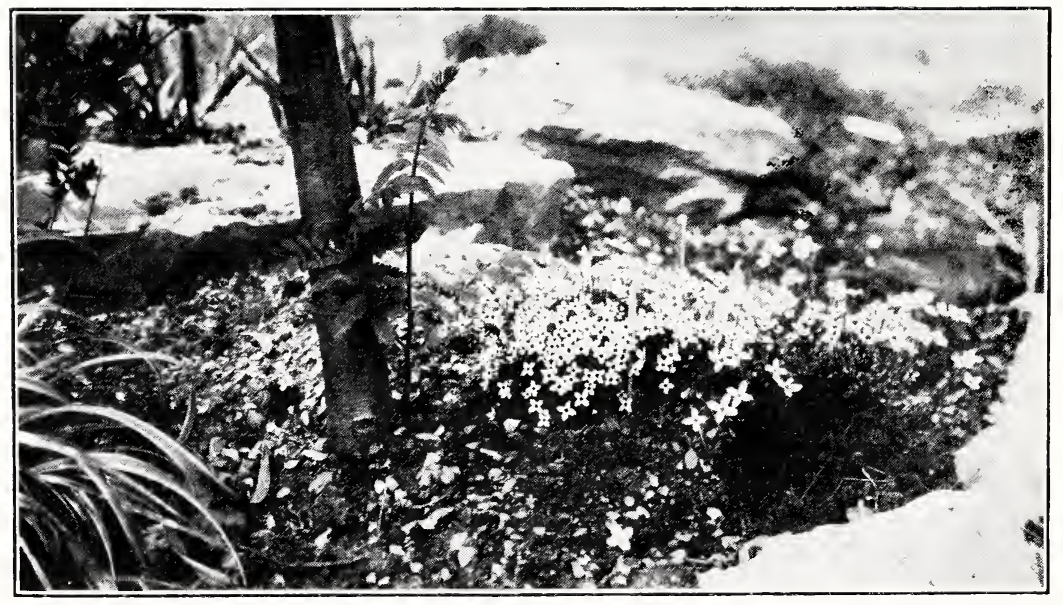




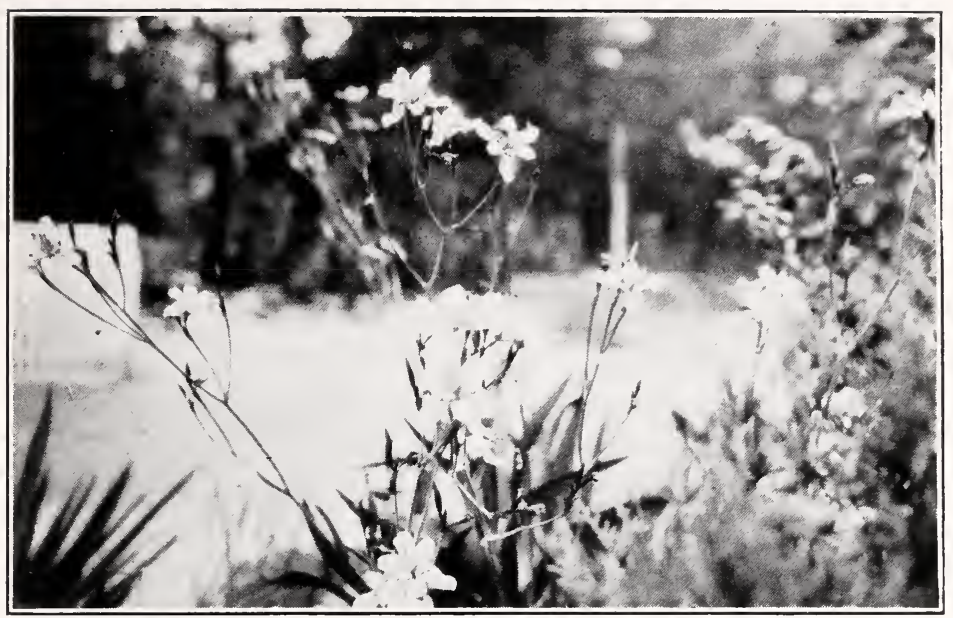

Iris dichotoma. Vesper Iris.

HYSSOPUS officinalis sends up a fine-looking clump of erect stems from a woody base, each ending in a purplish blue spike. It is a delightfully aromatic plant and quite decorative. It grows about 15 inches high and gets along in a poor soil. July.

See

Cut

Page

27

HYPERICUM repens is a trailing, gray-leaved, low plant with large, clear-yellow cups in June. It wants a sunny, sandy, warm spot.

IBERIS gibraltarica is a familiar, pale lilac-colored Candytuft.

sempervirens is the white-flowering, evergreen Candytuft. A very beautiful plant and showy in bloom.

IRIS Cristata. A lovely small, creeping Iris which makes large patches. Light green foliage, 5 to 6 inches high and shorter flowers stems, in May, with very pretty light blue flowers. Best in lightly shaded areas.

dichotoma. The Vesper Iris. A beautiful, tall Iris with flower stalks up to 4 feet high. Loose sprays of small, charming, lilac-rose flowers, about the size of those of I. gracillipes. The flowers open only for about three hours in the afternoon, a few each day. The flowering season lasts usually from July 15 well into August. This Iris thrives in any well-drained rock garden soil in sun or very light shade. It seeds itself freely in the garden and has attractive foliage. The seedlings flower in their second year. 
gracillipes is a very lovely, narrow-leaved clump of

foliage, about 6 inches high, from which rises, in May,

a most graceful display of pale rose-pink flowers on slender, leafy stems. It is a beautiful Iris for the rock garden, dainty and airy. It wants a gritty soil, rich in humus and a lightly shaded position.

lacustris is in many ways very like cristata, except that it has neater foliage, lower and not so likely to become unsightly after flowering time. Use it like cristata.

tectorum, tho' rather bold, is nevertheless a beautiful thing for the rock garden. It makes robust clumps of foliage, 10 to 12 inches high, with sturdy flower stems, topped in May with handsome, flat, violet-blue flowers. Of very easy culture, in sunny places.

verna is a hardy species from the South, with foliage up to 8 inches high and very pretty, blue flowers with attractive lighter markings, in May. A graceful, clear-colored thing in bloom. It likes shade, and humus in the soil.

JUNIPERUS squamata Meyeri is a twisted and oldlooking little silver-gray Juniper, a perfect miniature of a storm-ridden, gnarled and ancient evergreen on the edge of the timber-line. The bright silver foliage turns, toward winter, into beautiful violet and plum-shades. The very thing for the rock garden.

LEONTOPODIUM alpinum. Edelweiss. This wellloved alpine thrives most readily on any open slope or well-drained crevice in the rock-work. Keep it out of the hottest South exposures.

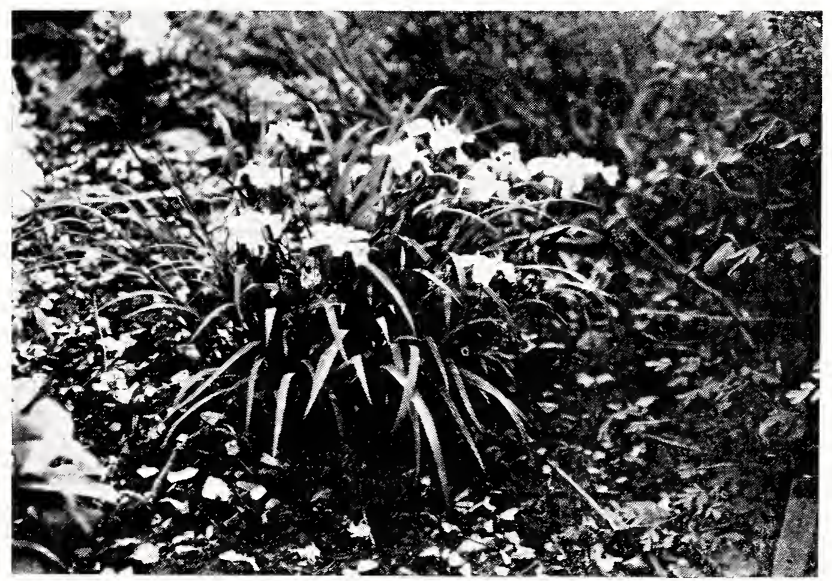

Iris gracillipes. A little plant of queenly grace. 
LINARIA alpina is a lovely little, gray-leaved, misty-looking plant which should be used in dry walls or up in the rock-work, where it may flop downward and display to advantage its pretty heads of purple with a bright orange spot in each flower. It comes into bloom in June and lasts all summer. It wants a sandy, light soil. It is not a very permanent plant but it seeds itself so freely that, once established, it will furnish you with enough seedlings to furnish the neighbor's garden. A very lovely plant for the rock garden.

aequitriloba is a very minute trailer, an almost microscopic and utterly prostrate Kennilworth Ivy; so tiny that no matter how ambitious it may be, it can scarcely ever be in the way of anything else. It is quite hardy but likes the warmer, light, well-drained spots and prefers to root along the edge of porous stones. It has tiny, purple flowers, all summer long. A most fascinating little thing. hepaticaefolia is a larger version of it, with a more rosetted habit. Its leaves rise scarcely an inch high and it has pretty, white flowers all summer. It creeps underground and likes to inhabit the porous soil between stones. It is a most lovely little weed.

pallida is a still larger thing, which makes its runners above ground. It is not as rank a grower as the Kennilworth Ivy, but makes short runners and rather compact masses of thick, grayish-green, minutely hairy foliage. It has light lilac flowers, all summer. It wants a warm, light and porous soil.

LINUM flavum is a yellow-flowered flax which comes into bloom about July first and continues all summer long. It is a very showy and pretty, dependably perennial plant, reaching about 15 inches high. For sunny, sandy soil.

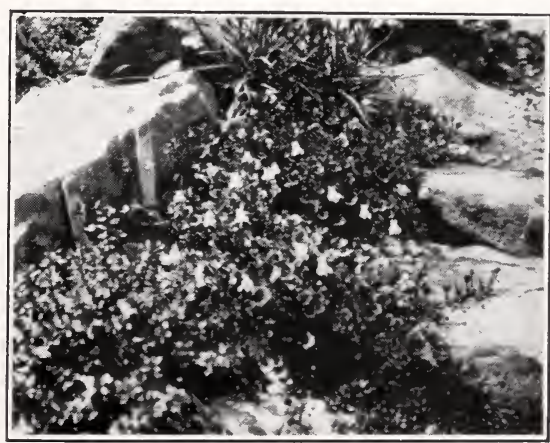


Page LONICERA nitida is a very beautiful, small, compact little

24 Honeysuckle of most pleasing growth. It has tiny, dark green foliage, which is not quite evergreen here, unless well protected. It makes an attractive little shrub in the back ground of the rock garden, best away from the brightest sun.

MAZUS rugosus is a very rapidly spreading groundcover plant for larger areas. It is unmanageable in the rock garden and even when used as a paving plant for walks will often prove too rampant. It is, however, a beautiful cover plant, with rich-green, lush- looking foliage and very pretty tubular flowers in eary summer, of a delicate lavender. It wants some moisture. It does not maintain a very good appearance in winter.

MENTHA rotundifolia. This is no rock plant. But it has here slipped in. On the way to or from the rock garden, in some lowly spot, plant a piece of this delightful Apple Mint that smells like a Baldwin Apple. And you will have better Mint Juleps and finer Spring Lamb.

MITCHELLA repens. The Partridge Berry or Squaw Berry makes a pretty patch in the shady nooks of the rock garden. It has the loveliest white, waxen flowers and bright red berries. Shade and acid soil will set it a-going. We offer potted plants.

MUGHO PINE. From this variable dwarf, broad Pine most interesting forms may be selected for use in the rock garden. They vary in vigor, in texture and habit. Especially desirable are the small-leaved forms. These may be improved by clipping the young candles in the spring, before they have unfolded their leaves. That way, one can grow very fine, compact plants, like pincushions. They are satisfied in the garden with a poorish, light, sunny soil.

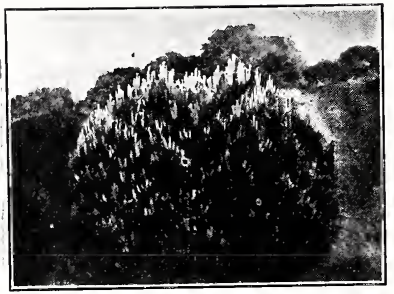

In the choice of a site for the rock garden, all other things being equal, select the coolest spot available.

A difference of a few degrees in summer temperature is a distinct advantage to the rock garden.

Pinus montanus mughus.

Mugho Pine. 


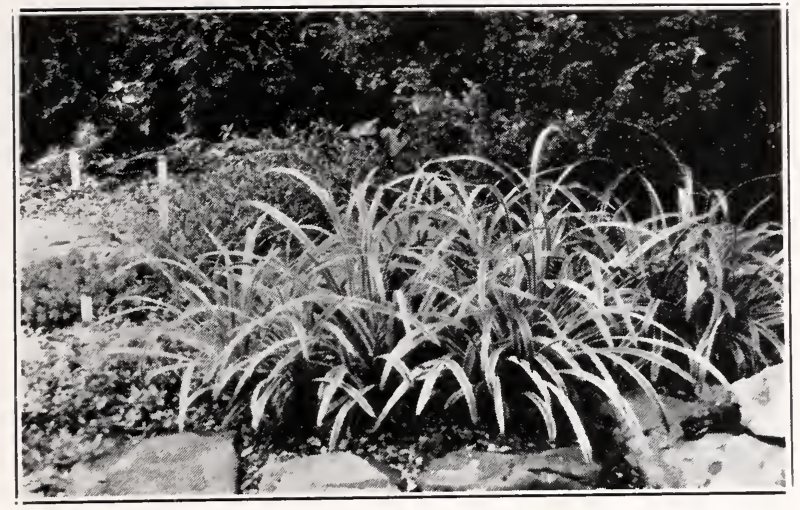

Ophiopogon jaburan aureo var.

MUHLENBECKIA nana. This is a little known little ground-cover plant of outstanding merit. A slow-growing, minutely shrubby mat, 2 to 3 inches high, of threadfine, black stems, clothed with tiny, round, blackish-green foliage. It is one of the darkest greens we know of. It trails along very slowly and is somewhat slow establishing itself, but once established is very permanent and hardy. Not evergreen, but one of the very finest matting plants for the rock-garden. A rare thing. We offer a very fine stock of potted plants.

OMPHALODES verna alba. A rather coarse-leaved plant for shady, dampish corners, which sends out trailing shoots with heart-shaped leaves, from which spring lovely white, forget-me-not-like flowerheads of pure white. A real woodland beauty, for early spring.

OPHIOPOGON jaburan aureo var. Under this impossible name sails a very showy plant with fleshy, grasslike, gold-striped leaves in very neat tufts, 10 to 12 inches high. In September, this plant fits itself out liberally with foot-high stems and spikes of giant Grape Hyacinths, in a rich royal purple. Give this plant a fairly damp, light soil, and, unless you have been made to forswear all variegated things at all times, you will find this a very handsome plant, especially in September and October, when it flowers. It is usually grown by florists as a tender greenhouse plant but it will be found perfectly hardy.

OPUNTIA vulgaris is our native Cactus which hangs down from bare, rocky slopes in great wads of leathern foliage, adorned in late June with large, yellow, beautiful flowers. Any hot, barren sort of place will do for it. 
PACHYSANDRA terminalis, the Japanese Spurge. The

"Magic Carpet" for shaded and difficult areas, under

trees. Plant it thickly and it will form a beautiful, evergreen, solid carpet.

terminalis argenteo var. This is a white-variegated form of Japanese Spurge, effective for edgings, etc.

PAPAVER nudicaule. Iceland Poppies. These lovely, tho' not permanent, graceful, long-stemmed, Poppies should always be planted and replanted in the rock garden. They do well in light, sandy, sunny soils.

nudicaule, Thibet. This is a charming strain, somewhat later to flower than nudicaule type. It is a beautiful, tangerine form, a little heavier of flower.

PENSTEMON diffusum. A rather robust, spreading clump with clear-blue, bunched flowers on 8 to 10 -inch stems, in June. Of easy culture in well-drained soil, rich in humus.

PHLOX amoena. A popular spreading, low Phlox with bright rose-red flowers on erect, 6 to 8 -inch stems in early spring.

amoena, variegated. This makes cheerful patches of brightly colored foliage, somewhat less robust than the type. An old-time plant but now rarely offered.

canadensis (divaricata). An excellent, spreading, Mayflowering Phlox with lavender-blue flower heads. It is a fine thing for naturalizing in shady places.

canadensis, Laphami. A clearer-blue form of great beauty.

canadensis, alba. A form with very faint lavender, practically white flowers.

ovata (carolina) flowers later than canadensis, in late May or June. It is a spreading plant with strong, glossy, deep green foliage and foot-high stems, topped with glowing, magenta-rose flowers. Best in light shade.

A good mixture for the average run of rock plants: one-third light loam, one-third sand and one-third humus or leaf-mold. Add to this one-fifth fine gravel or $3 / 8$ screen crushed stone.

So far as acidity is concerned,---a practically neutral mixture will do for the average run of plants.

Peatmoss added to the mixture will help retain moisture and have a slightly acid effect upon the soil. This may be neutralized, if desired, by the addition of a little lime. 


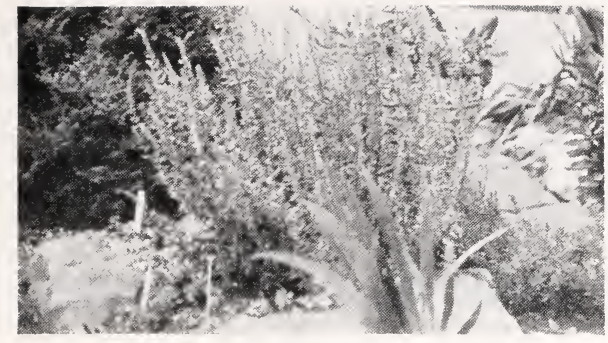

When occasionally you replant a section of the rock garden, re-soil it as well.

There is nothing like new soil for plants to thrive in.

Hyssopus officinalis. Hyssop.

pilosa splendens. This is a less familiar species, of erect growth, with flower stems up to 18 inches high. Terminal clustres, in early June. Long, narrow, pointed foliage. The form we offer has lilac flowers of a pleasing, soft shade. Best in dry open or lightly shaded places.

procumbens is a low, trailing plant with light-green, broad, hairy leaves and flower-stems rising up to 8 inches. Heads of lavender-blue, similar to, but longer tubed than those of canadensis and less showy in flower. It makes large patches of light-green foliage, in sun or light shade. reptans (stolonifera) is a trailing Phlox of especial charm. It makes a loose, prostrate mat of light green, broad, downy foliage and reddish, rooting runners. In April or May there rise, here and there, erect, 6 to 8 -inch reddish stems, topped with nodding flowers, in loose, sparse clusters, of a glowing and pretty rose-carmine shade. It is a pretty thing, of neat habit and attractive in flower, especially in the rose-carmine form which we offer.

subulata alba needs no description.

subulata lilacina is a rampant spreader with lovely pale lilac flowers, flowering with or a little later than subulata type.

subulata Vivid. Thus is Phlox subulata made welcome to the larger expanses of the rock garden,--dressed in pure salmon pink and shorn of its most rampant manner. A most lovely transfiguration of old subulata.

PHYTEUMA scheuchzeri. A graceful plant which makes a thin tuft of light, graceful foliage, from which rise slender stems, 15 to 18 inches high, tipped with pretty, somewhat thistle-like, round heads of blue flowers, in June. It grows readily enough in a well-drained, open soil.

PINUS montanus mughus.. See Mugho Pine. 
Page POLEMONIUM pulcherrimum is a Jacob's Ladder of neat tufted habit, making tidy clumps, 10 inches high, with numerous flower stems rising gracefully, in May. It wants a shaded spot and does best in a dampish loam. reptans also makes a neat, smaller clump of foliage, 6 inches high, with flower stems rising well above it, in May. It has a creeping rootstock, by means of which it spreads and forms dense colonies.

POTENTILLA alba. A rather large plant with pretty, palmately divided foliage, about 8 inches high, from which splash out graceful sprays of large, white blossoms in spring.

aurea is just a larger version of verna nana, with mats as high as 3 or $31 / 2$ inches, somewhat more robust, tho' slowly spreading and with taller flower stems. It wants the same treatment as verna nana.

rupestris pygmea. Low tufts of long-stalked, composite leaves not unlike small rose-leaves. From these 2 inch tufts rise numerous small sprays of white blossoms in spring. A very pretty little thing of easy culture.

tonguei is a very free-flowering, rampant and beautiful, roving Potentilla with long runners in mid-summer, on which numerous brilliant, apricot flowers are borne, with orange-red centers. The showiest of creeping Potentillas, easily-grown in a well-drained, sunny soil. Beautiful and rare. It wants room to spread, and deserves it.

tridentata is an evergreen with dark green, leathery foliage which grows in rocky woods and makes very pretty dark patches. It has numerous sprays of small white flowers in late summer. A nice thing to establish in the shady nooks of the rock garden. It has vigorous creeping rootstocks, by means of which it makes sizable patches. 6 inches high.

verna nana is by far the prettiest and showiest of the early-flowering matting cinque-foils. It makes a dense mat, 1 inch high, of dark-green, shiny foliage, which is often completely covered in early spring with a blanket of bright yellow buttercups. It spreads slowly and belongs in well-drained, dry, sunny places.

An occasional top-dressing will benefit many plants. Fine leaf-mold with a little sand will do for this, or, in the case of acidity-loving plants, just peatmoss, with or without sand. 
PRIMULA Bulleyana is a beautiful, robust plant with tall

candalabra stems and flowers of a fine, lovely orange-rose. It wants a rich and damp loam. A very fine plant. July.

denticulata makes its appearance in the spring like a very small and modest Primula with wee, rosetted leaves and globular, soft lilac flower heads on three inch stems. These little stems continue to stretch until the fully open head stands a foot or more high and the seed-heads reach yet much higher. The leaves, meanwhile, develop as large or larger than the lustiest P. japonica, so that, by midsummer, shy and modest denticulata of early spring has become an imposing and fat personality of japonica-like propensities, with longer, narrower leaves, about 15 inches long. It increases lustily in the rich, dampish nooks of our garden and is a very charming thing in early spring.

denticulata cashmiriana is exactly like this, except that the reverse of the leaves is powdered with a golden meal.

florindae. A handsome, robust plant with heads of large, drooping, yellow flowers and strong, deep green, heart-shaped foliage. For rich, damp loam.

frondosa. This proves with us one of the loveliest and best and easiest of small, spring-flowering Primulas. It makes small tufts of crinkly, grayish leaves, from which rise round scapes of soft lilac-rose flowers on three-inch stems. It does well, can be divided easily and is altogether a pretty little thing, which should be added to the garden forthwith. We have it in well-drained, sandy loam, in very light shade.

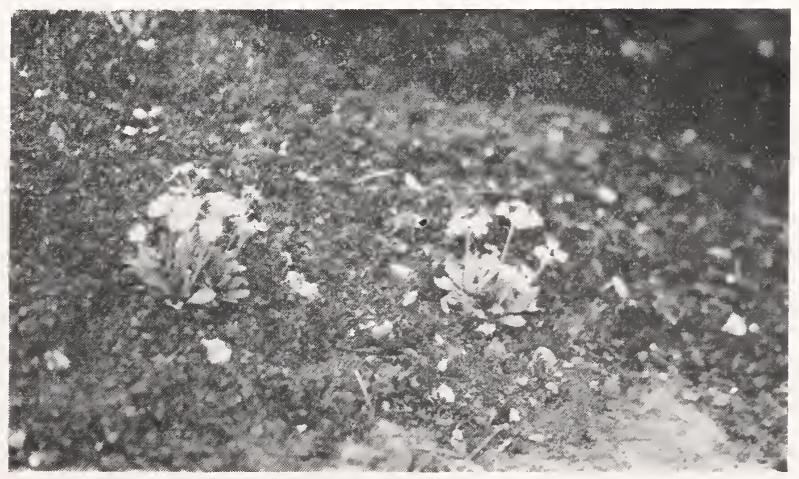


longiflora, with us, rises a little higher than frondosa, from a similar small tuft of foliage. The flowers are more bluish-purple and have long tubes, which makes for a less solid, less showy quality in the flower-head.

polyantha. Colorful, bunched Primulas in all shades and combinations of shades. They are easy to grow and most delightful things in and about the rock garden.

vulgaris is the Common yellow English Primrose, which looks well in shaded, woodsy nooks and corners.

PULMONARIA azurea is a fine spring-flowering thing for dampish, shady corners, with ten-inch stems topped with Mertensia-like, clear azure flowers. These flowers, when first they open, are bright rose, changing to blue later.

RHEXIA virginica is a bog-plant, with erect, foot high, four-winged stems and light-green, 1 I/2-inch long leaves and reddish-purple flowers. A pretty, tho' sparsely flowered thing for late summer. It will grow in any fair, dampish soil.

RUELLIA ciliosa. A little known American plant of the Acanthus Family. It makes a very neat, foot-high plant with rather erect stems, oblong, hairy leaves and with pretty, pale-lavender, long-tubed, funnel-form flowers. It comes into bloom in July and continues very long. It seeds itself in the garden and will be found a much worthwhile plant in almost any fair soil, in open places. Rare.

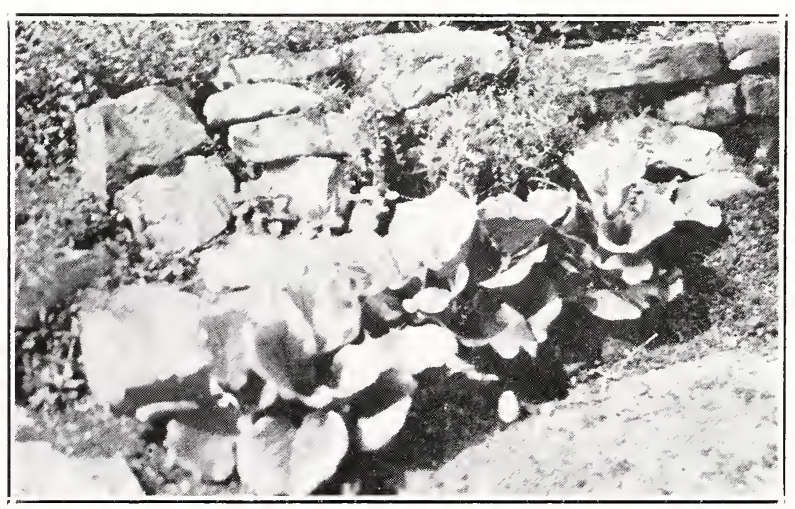


SAXIFRAGA apiculata is a tiny little sod with yellow little flowers, early in the spring.

crassifolia and seedlings of it. These make impressive plants with very large, leathery leaves which may well be considered, outside of the rock garden, for mass-plantings in front of evergreens. They grow with perfect freedom in any not too dry or lean loam, in sun or shade. The foliage is evergreen, the leaves lying flat on the ground in the spring, but returning to their normal position with the advent of mild weather. They send up thick, fleshy stalks in very early spring, topped with heads of large peach-blossoms. Effective in the back-ground of the rock garden.

stracheyi is a similar plant which blooms about three weeks later and so escapes frost-bite to the flowers, which often spoils the blossoms of crassifolia. It has large, branched flower-heads of irregular outline.

sarmentosa is the Strawberry Begonia of the florists, who let it trail over the edge of the greenhouse benches. If planted in shady, damp nooks, it will prove entirely hardy. It makes large patches, from which the long, thready, red runners trail out in search of cool, damp

See

Illustration

Page

18 spots to root in. It flowers well outdoors. The foliage is very decorative, gray, round, and veined white.

umbrosa. London Pride. 'This makes rather large patches of large rosettes with think, fleshy, deep green leaves. It makes flowers stems up to 10 inches, with pretty, dainty flowers, pinkish in effect and very effective when massed. It grows lustily in shady places, in good loam.

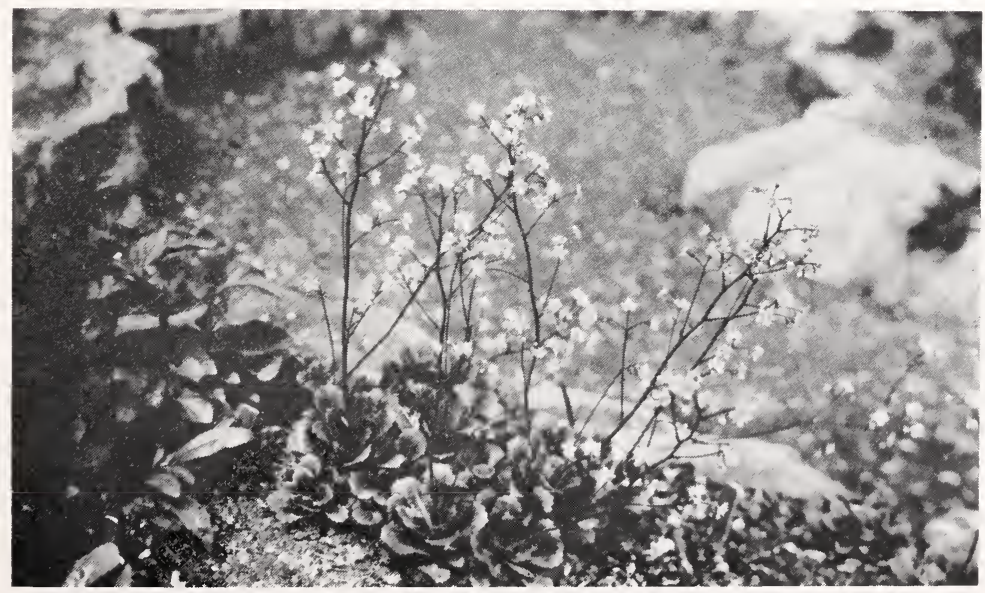

Saxifraga umbrosa London Pride. 
The following Saxifragas should be planted in the coolest, open locations available in the rock garden. A North slope or the shade of a large rock is desirable. Avoid hot, south exposures. They may be planted in deep, gritty, well-drained soil or in deep, drained crevices of rocks. They will thrive in practically neutral soil, which may be slightly alkaline or acid.

aizoon emarginata is a large aizoon with rather loose rosettes and flower stalks from 8 to 10 inches high. The flowers are not distinct;-typical, creamy white aizoons. aizoon lagaveana (lagraveana). This is a tightmatting, flat cushion of very small, silver-beaded rosettes; a lovely thing for its fine matting habit. One of the most valuable of aizoon forms in the garden. The flowers are small and dingy. Use it only for its fine cushions.

aizoon rosea stands out for its truly pretty, clear pink flowers. It makes a small, tight clump of rosettes and carries its flowers on 7 to 8 -inch stalks. It is comparatively easy to grow and proves a perfect little beauty for the rock garden.

andrewsi is a cross between umbrosa (London Pride) and aizoon. It has the lusty, large rosette of umbrosa and the silver beads of aizoon. It makes a rather erect, cupshaped rosette, with flowers after the style of umbrosa. It is an easy doer in well-drained, gritty, lightly shaded places.

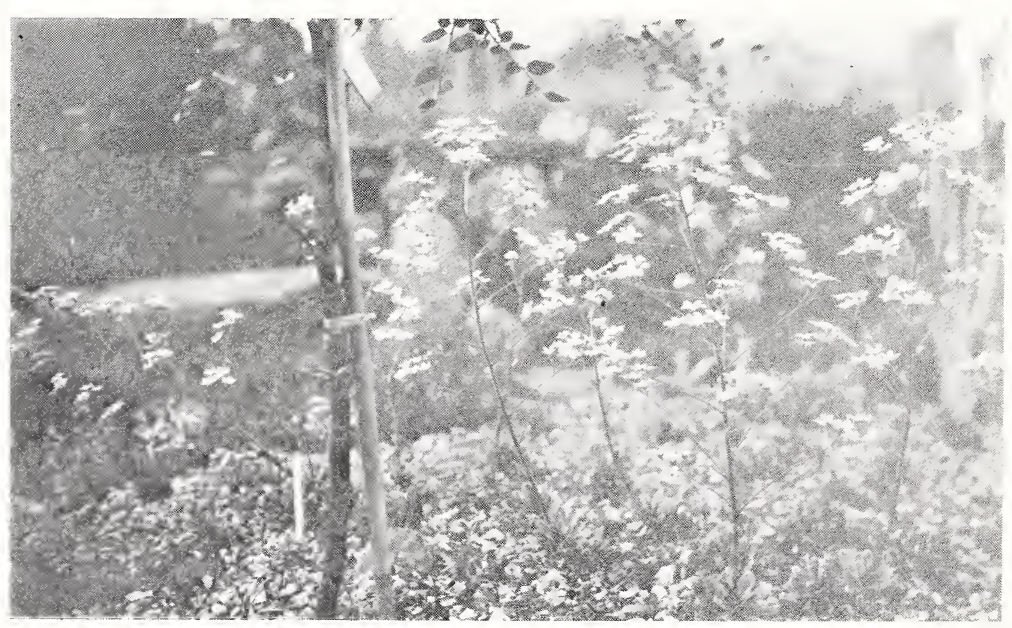


cartileginia might well be a stitff-leaved, robust form of aizoon, from which it does not differ in flowering qualities. It grows very freely and produces numerous offsets. It makes a broad, flat mat of gray rosettes.

cotyledon X longifolia. This is an excellent plant, free-flowering, showy in bloom and producing offsets freely. The rosettes are much smaller than those of cotyledon. It makes robust stalks, branched at the top, from 10 to 15 inches high, more or less arching. The flowers are creamy-white. A good group of this hybrid in bloom makes a charming and impressive picture.

macnabiana. Under this uncertain name goes a fine hybrid, probably of cotyledon and aizoon. It is one of the easiest to grow. It makes robust rosettes and clumps, 3 inches or more in height, with sturdy stalks, in May, from 10 to 18 inches high. White flowers, finely peppered with purple. A most satisfactory and fine-looking Saxifraga.

Reserve the places to the north of large rocks for the more difficult and choice plants. They may be ideal cool spots for Saxifragas or other fine plants.

Saxifraga cotyledon X longifolıa, showing the rosettes.

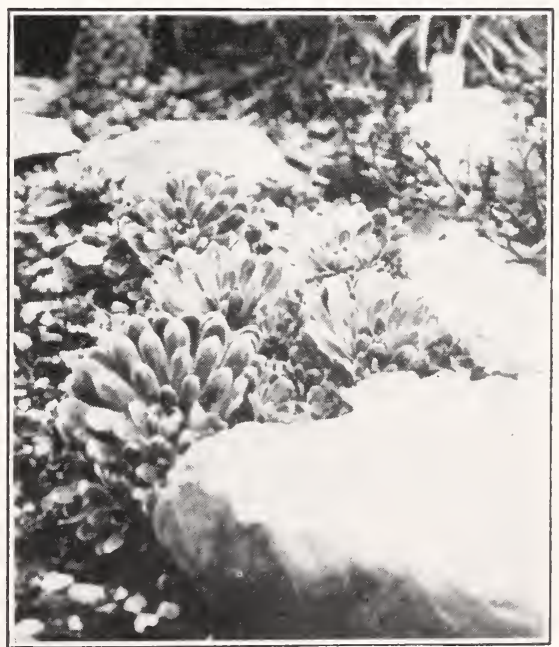

EThe same hybrid, in bloom. 
Page SAXIFRAGA, Mossy. The following Mossies are per-

fectly hardy but, with the exception of ceratophylla, suffer more or less during the heat of summer. The coolest place suits them best, in open or partly shaded locations. They like to grow amongst stones. Top-dressing in summer with leafmold and sand may prove beneficial. Mossy Saxifragas are planted both for their flowers and for the effect of their rich-green cushions. They bloom freely, in the spring. With the advent of hot weather the foliage may turn brown. They are hard to keep in good condition in summer, but are nevertheless worth planting again and again.

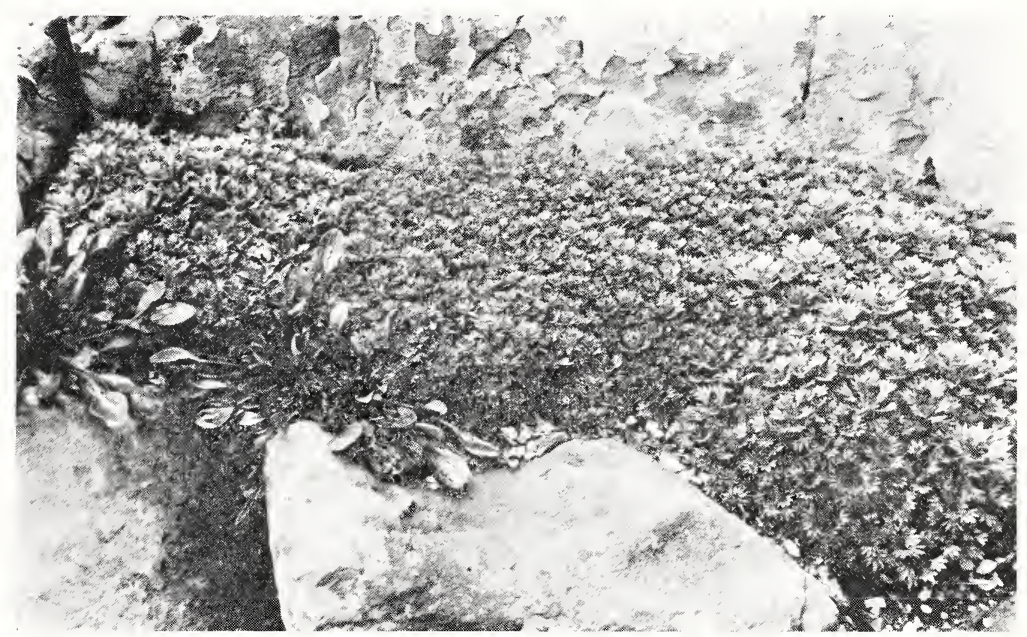

Mossy Saxifragas make lovely cushions in the garden.

SAXIFRAGA decipiens. The most familiar of the Mossies. It makes large, bright green cushions and flowers very freely on stems rising a few inches above the foliage. decipiens, deep pink. A selected form, raised from divisions, with deep-pink flowers, blood-red in bud.

decipiens, Stoke's Hybrid. A pink-flowering form with small, compact cushions of stiff, leathery foliage, bright green and fairly heat-resistant.

ceratophylla. This is by far the best and most dependable of the Mossies, completely heat-resistant. It makes a large mound of stiff, leathery, dark green foliage, from which rise, in June, long, frail stems, up to 10 inches high, gracefully carrying sprays of white flowers. It is 
a beautiful thing, and, if kept out of the hottest exposures, can be depended on to come through the summer in fine condition. It divides readily and should be divided from time to time.

wallacei makes a bright green cushion of softer foliage and looks more like decipiens. It is somewhat more heatresistant and carries tall sprays of white, somewhat bellshaped flowers, in late May or early June, well after decipiens. It is a more graceful thing in bloom than decipiens.

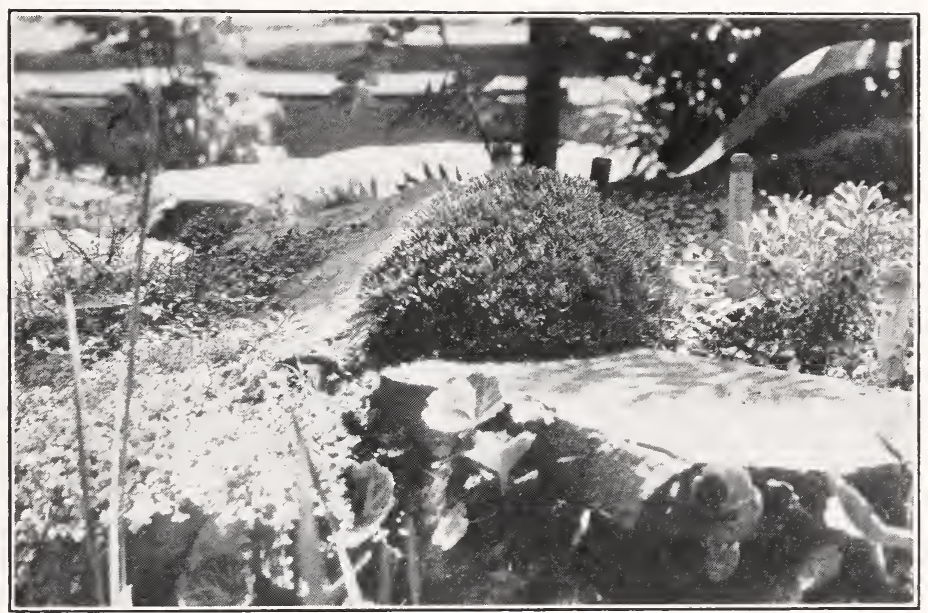

Saxifraga ceratophylla is a most distinct Mossy.

SCUTELLARIA aIpina nana. We offer a very fine, small form of this Skullcap, which makes a spreading mat of grayish-green foliage, not over 5 inches high. It has spikes of clear lavender-blue flowers in July. A desirable, low form. We grow it in a light, porous soil, in full sun.

Do we advise winter protect on for the rock ga:den? Yes, most assuredly.

Especially those plants which retain more or less of foliage throughout the winter will come through much better when properly protected.

The lightest, airiest winter protection is probably hemlock boughs.

In climates like ours at Poughkeepsie, do not apply the winter cover until real hard frost. If heavy snow falls early and stays, keep the Hemlock boughs handy until the the snow melts. Then, to prevent heaving and to keep the ground insulated, apply the cover.

The winter cover is best removed gradually. Just when to remove the cover is always nore or less a matter of gambling. 


\section{SEDUM. STONECROP}

We carry a large assortment of species and forms of these most versatile, useful and beautiful Stonecrops. All our stock has been definitely checked against Praeger's Monograph of Cultivated Sedum and are named in an orderly manner. We list certain of the American species and forms not described by Praeger.

Descriptions are made from our observation of the different species and forms in our trial garden. In the case of variable species, we describe the particular forms offered by us.

SEDUM acre. Wall Pepper. We offer a selected, native, local form which makes bright green mats, less than an inch high, retains that bright color in winter and flowers lemon-yellow.

acre majus is a robust form, twice as large in all its parts as average acre. It has light green foliage, up to 4 inches high. A rare form.

aizoon. Of this very variable species we offer a form with foot-high stems, which may spread apart, and with large flowerheads of deep-orange effect, in July.

aizoon X kamtchaticum is of botanical interest as one of the very few known hybrids. It is intermediate between its parents, with lax, yellow flowerheads in late June or July.

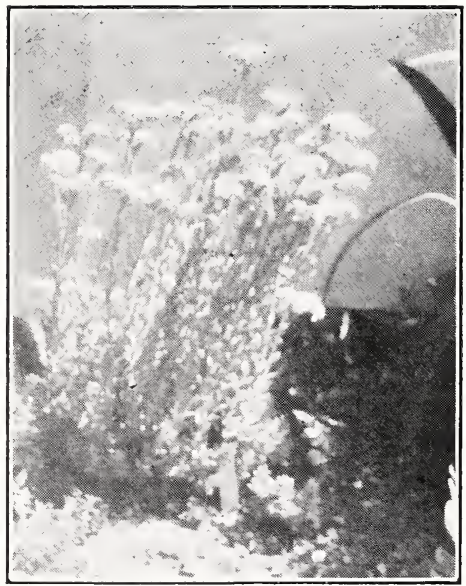

Sedum altissimum

is a very striking plant.

Most rock plants withstand drought more easily than excessive moisture. 
alboroseum variegatum makes a dense, erect clump, after the general style of spectabile, with bright, yellow-andgreen foliage and flowerheads of palest-rose effect, almost white, in August or September. Not very suitable for the rock garden.

album, green form. S. album is a common plant, the better forms of which make matchless evergreen groundcovers, in sunny or lightly shaded areas. This green form spreads too rapidly for the rock garden. It is covered, in July, with a blanket of pure white flowers. S. album deserves to be used freely as a groundcover plant. It matches the green of the dwarf Japanese Yew.

album, bronze-leaf form. This is a somewhat less rampant, bronze-leaf form, less suitable as a groundcover, but fine for unimportant areas in the rock garden.

album, compact form. This is a thick-leaved, compact, comparatively slow-growing form for the rock garden. It makes beautiful clumps, which in exposure to cold or drought turn bronze. The flowers are sometimes light blush instead of white.

altissimum. A valuable, beautiful, gray-leaved plant for the rock garden, with thick, fleshy, linear leaves. In not too poor, gritty soil it makes a dense clump of bright gray, which toward winter blends into purple and plum shades. Creamy-green fowerheads are carried on spiry, erect stems, in July. These flowers, while not of striking color, are very effective. It is one of the best Seda for the rock garden.

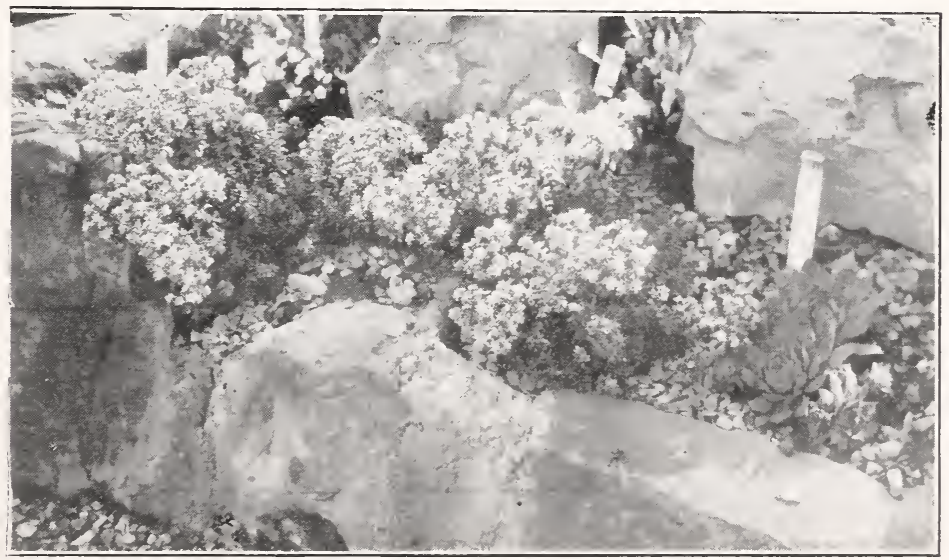

Ssdum album, - $a$ fine, compact, dwarf form. 


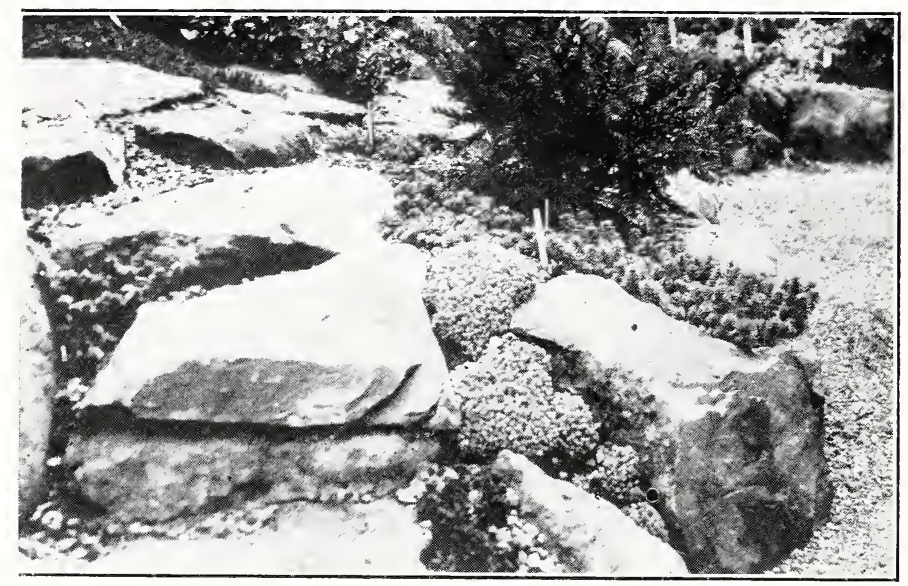

Center, cushions of Sedum dasyphyllum. Right, Sedum rupestre.

amplexicaule or tenuifolium is of botanical interest and serves to demonstrate where the name tenuifolium, often applied to S. album, belongs properly. A small, creeping, bright green plant which may send up weakly stems in June, with yellow flowerheads. After that the foliage shrivels and the plant plays dead,-utterly dead and brown, until in the fall, in hope of cool moisture, it resumes activity, greens up and then goes through the winter like a respectable little evergreen Sedum.

anacampseros, for reasons unknown to us, according to its name, causes Eros to return. Whatever gave it its name,-it makes thin mats of creeping, woody stems, from which rise young stems, a few inches high, clothed with gray, oval leaves;-tapering little towers. These are topped, on rare occasions, in the fall, with purple flowerheads. The plant flowers very little but makes a pretty gray drapery over stones. It likes a good loam, not too dry.

anglicum is a choice little mat, grayish or bright green, about an inch high, covered in June with starry, white, pink-flushed flowers. Pretty in sunny, porous, light soil. inch high. 
anopetalum. As we have it, it looks like a small, gray

form of reflexum, which makes thin mats and sends up erect, 5 to 6-inch stems with greenish-white flowerheads, in June. It is not a showy, nor a rampant thing and quite worth having.

dasyphyllum is a tiny, gray, pimpled mat of the greatest decorative value in shallow soils and amongst the stones. It makes very dense patches or mounds, covered in June with little flowerheads of white or pale, smoky pink. It is best to shear off these little stems directly after blooming, so that the plants will resume their normal, tight growth as soon as possible.

dasyphyllum glanduliferum. A markedly hairy form with the leaves so loosely attached to the stems that the rain or the slightest touch will disperse them about the plants. Many of these fallen leaves root and sprout, thus forming dense masses of growth.

dasyphyllum macrophyllum. This is a larger form than the type, quite beautiful. We grow it in a richer soil and find it a very striking form. It flowers white. Rare.

divergens is a very pretty thing which forms thin mats of trailing stems, from which the young stems rise up to 2 inches high, clothed with small, thick, shiny green or bronze leaves. A most decorative thing which flowers yellow, when it blooms, which is seldom. It wants a sunny, dry, gritty soil with humus in it. It is a western species.

ewersi is a shrubby little bush, 10 inches high and wider than that, with gray, rounded leaves, which does best in fairly good loam in light shade. It has purplish flowerheads at the end of the stems, in the fall. It blooms seldom. This is not a choice species for use in the rock garden, but looks well peering out from under a larger shrub, in the background.

Let us remember that the plant values which enter into rock gardening are different from those that make up the flower garden.

The rock garden is not merely an informal gathering of horticultural celebreties.

It is more nearly an attempt to gather the wildlings of mountain. woodland and roadside, from near and far, into a happy environment and into a harmonious scene which reflects the mood of the natural rock formations of the locality. 
ewersi homophyllum is a little gem. It makes a small, flat little patch of clear gray foliage, up to $1 \mathrm{I} / 2$ inch high. It does best in not too dry or poor loam. It has never flowered here, but its foliage and neat habit entitle it to a choice place in the rock garden.

forsterianum or pruinatum forsterianum does not exist. Plants offered under this name are usually S. rupestre, the larger of the forms we offer. See S. rupestre.

glaucum is not any hardy Sedum. Plants offered under this name are most often $\mathrm{S}$. hispanicum, which see.

gracile. This is a small Sedum of the stature of $\mathrm{S}$. lydium;-intermediate in effect between lydium and a small sexangulare. It makes low patches of bright green, soft foliage, topped with a faint-blush flowers in June, after the style of anglicum. But this plant is particularly fine and distinct in its winter form, which presents a tight cushion of dull-green moss. If only for this reason, it is entitled to a place in the rock garden.

hispanicum. We offer a perennial form of this, which makes broad patches of bright bluish-gray foliage, up to 2 inches high, topped with a misty spread of pale-rose flowers in June. The foliage is linear and the stems thin and thready. A very pretty mat if planted in fairly damp soil. In hot, dry places it may become unsightly. It seeds itself freely in the garden and the offspring is very variable, - largely of an annual or biennial nature.

hispanicum minus is a choice little thing for dry, sunny places. Less than an inch high, bright gray, shortleaved, it makes a pretty, solid little mat. It blooms shyly and does not flood the garden with seedlings. It might be mistaken for a gray form of lydium. It is, in fact, the "S. lydium glaucum" of "Standardized Plant Names".

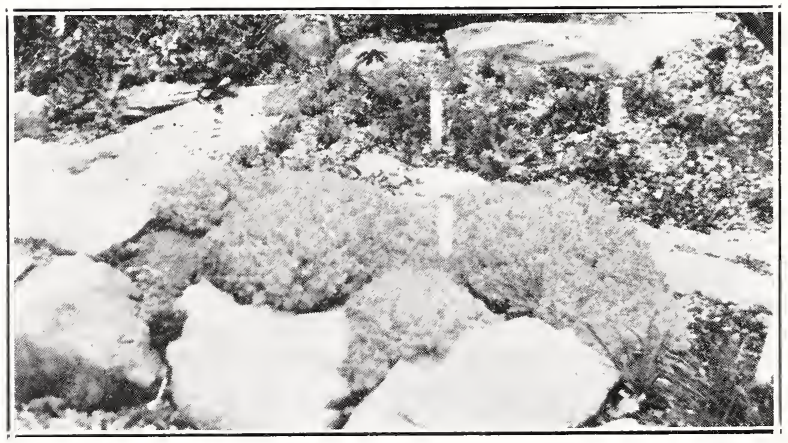
hispanicum. 
There is no objection to the use of any suitable plant of horticultural lineage so long as it retains something of the charm and shyness of the wildling.

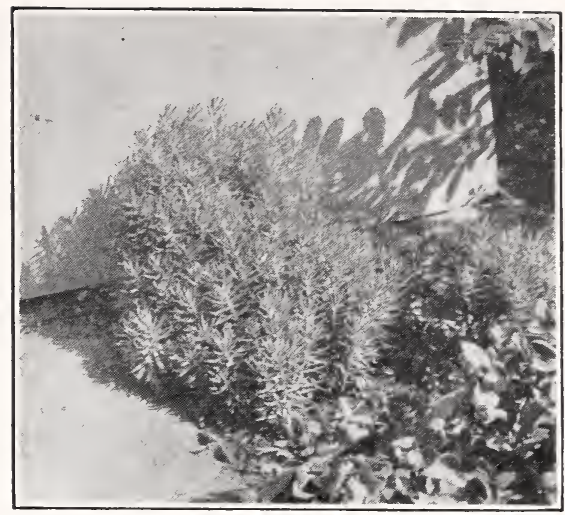

Sedum lineare robustum.

hybridum is not a hybrid, but an excellent, evergreen, trailing and matting species after the order of spurium, but better, with more and richer green, shiny foliage. It makes solid carpets or borders, topped in June with bright yellow flower heads, well above the foliage. It is one of the very best evergreen groundcover plants for sunny or shaded places and deserves to be used much more than it is. kamtchaticum is not a creeping Sedum but makes a rounded, broad mound, 6 inches high, topped in June or July with showy, orange-yellow flowerheads. It is a pretty plant, rather large for the rock garden, but effective in the hardy border or as an edging. It is not evergreen. It dies down in the fall to its shrubby base.

kamtchaticum variegatum is a very pretty creamyellow-and-green variegation of the type. The orange yellow flowers, with a great show of red carpels, blend well with the foliage. The plant is rather lower, flatter in its habit than the type, seldom over 3 inches high in our garden.

lineare robustum is a very decorative, dense, erect bush, up to 10 inches high, made of sarmentosum foliage and thick, fleshy stems. It has gray foliage, with an occasional white branch. It has never flowered here but makes a very pretty bush, eligible for choice places in the rock garden. It likes a porous, light soil and some moisture. lydium. This makes a lovely inch-high patch of fine, mossy foliage, deep green in richer soils and reddish in poorer, dry soil. One of the prettiest of the small Seda, not rampant, and with pretty, pink flowerheads in July. It will grow in any reasonable soil. 
middendorfianum, in summer, makes a dark green,

loose mound of glossy, long, toothed foliage, topped, when it does bloom, with lax flowerheads, leafy, and of a cold, hard yellow. After a while, in late summer, these old stems die off and reveal the short, crowded new stems already sprouted from the base. These stems remain short and the winter form of the plant is thus, - a close-cropped, tiny mound of very short, bronze-leafed foliage,-very pretty indeed. The plant flowers only rarely.

nevi. This is a very decorative, hardy species from the Southwest. It makes flat, slowly-spreading mats of grayishyellow foliage, arranged in rosettes. The plant sends up stems from 3 to 5 inches high, topped with white, fuzzylooking flowerheads. It does best in gritty soil, rich in humus, rather dry and in light shade. It follows $S$. ternatum in bloom and flowers freely. A very pretty Sedum for the rock garden.
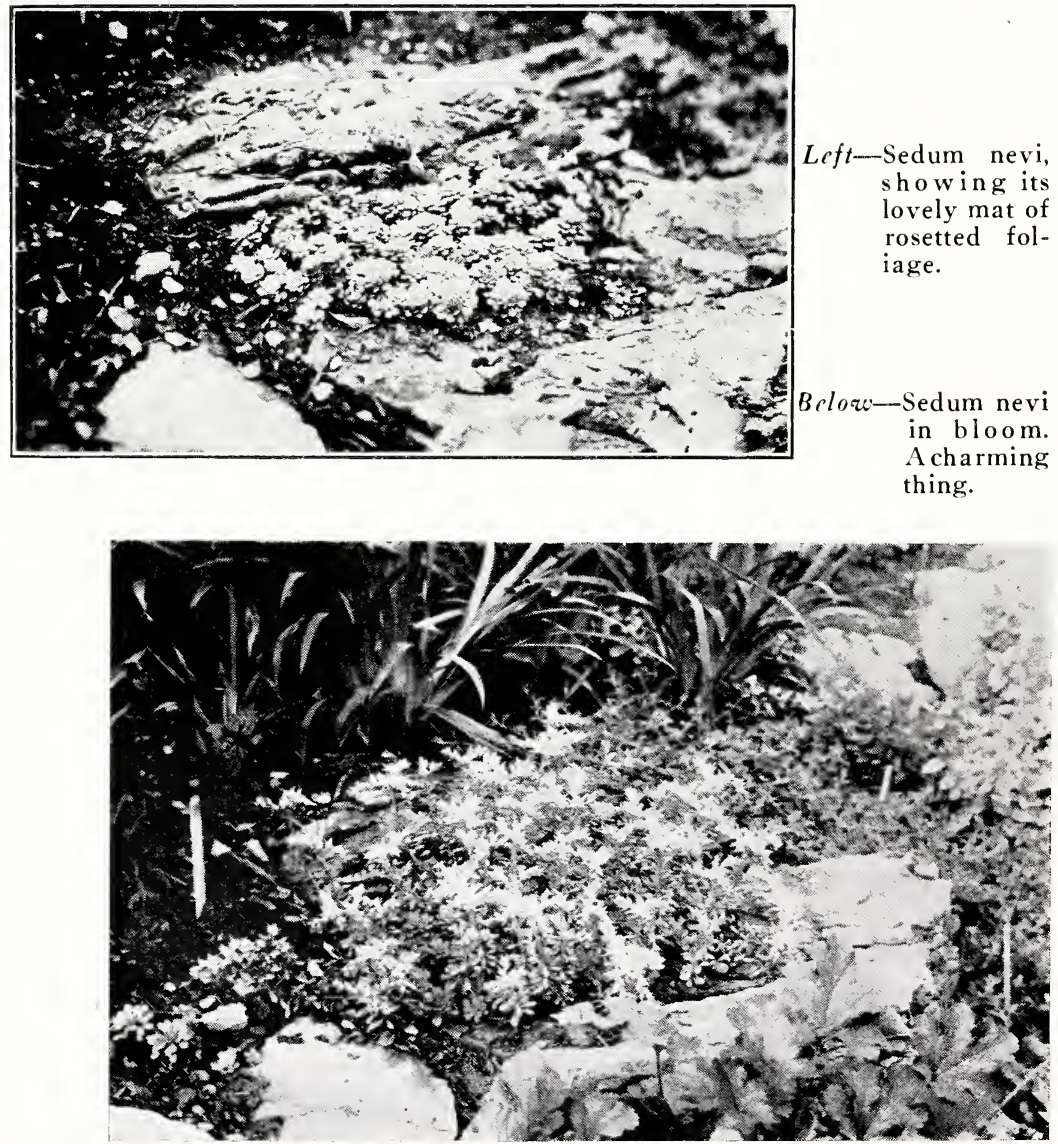
nuttallianum is a pretty annual from the Southwest,

not described by Praeger. It grows up to 4 inches high

and is, in flower, a glorious bit of yellow lace. It makes large, airy flowerheads with wide-flung prongs. After the plants die, the young seedlings come up in vast numbers. These go through the winter quite small and bright green, much like the seedlings of annual pulchellum. A beautiful thing for light, porous, sunny soil. We offer only the young seedlings from the garden, in fall or spring.

oreganum (Gormania oregana) A fine Western species with thick, fleshy, paddle-shaped, deep green, sometimes bronze foliage which bears showy heads of brilliant yellow flowers in July. The plant makes small patches, $31 / 2$ to 4 inches high in bloom. It is not easy to grow. It seems to want a gritty soil, rich in humus and either full sun or light shade. It is often listed in foreign seedlists as $\mathrm{S}$. obtusatum, which, however, is quite a different thing.

populifolium is a shrubby little plant, up to a foot high, with stalked leaves, more or less like poplar-leaves. A slow-growing, unobtrusive, neat little thing. It is not evergreen. The white flowers, said to be fragrant, are not showy.

pulchellum. There are two distinct forms of this fine Sedum, one perennial and the other annual. The perennial form makes a low mat of bright green, lush-looking foliage, tipped in late summer, winter and spring with bright orange-brown. It is an exquisitely beautiful color effect. 'This perennial form wants a sunny, very damp soil; the edge of a pool will suit it. It sends up short flowerstems with wide, recurved, claw-like cymes of soft lilac flowers. These are really beautiful. The older stems die in late summer and the new stems develop partly before winter. The winter form is a close-cropped mass of short stems, bright green, tipped with orange.

pulchellum, annual form. This form flowers like the perennial, but it makes a small plant, which dies directly after flowering. The numerous seedlings rise in early fall and remain small until spring. They are bright-green. We offer only these young seedlings from the garden. This annual form is not described in Praeger's Monograph. 


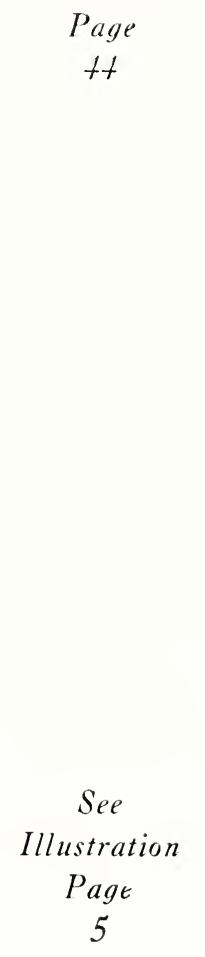

reflexum. A very variable species, of which we offer two distinct forms, one gray and the other bright-green. They make rather robust mats, 4 to 6 inches high, with almost linear, thick leaves, from which rise robust flower stems, up to 9 inches high with yellow flower heads in June or July. They are easily controlled and quite admissable to the rock garden.

reflexum cristatum is a green form of which the barren shoots are crested,-flattened into queer shields. A very striking, odd-looking thing. The flowering shoots develop normally.

rupestre, strange to say, is often confused with reflexum and said to be difficult to tell from it. An unfailing characteristic of rupestre is the presence of old, shaggy, withered leaves on the older parts of the stems. Another mark of rupestre is the straight-down, hook-like droop which the inflorescence, in bud, develops at one or other stage of its career. Also, the thinner, less fleshy leaves. Rupestre is one of the most decorative and useful of all Seda in the rock garden. It thrives in the poorest soils and makes lovely patches of gray, if it is not utterly starved or abused.

We offer two forms, one larger than the other. The larger form does not discolor as strikingly in winter but makes beautiful patches of misty gray foliage, about $1 \frac{1}{2}$ inches high. It sends up rather woody flowerstems, in June, with bright yellow heads.

rupestre, small form. 'This small form assumes beautiful reddish or purple shades in the fall and retains this coloring well into spring. A most decorative thing.

sarmentosum is a beautiful, rampant thing which must be kept out of the rock garden if you would grow anything else in it. It needs room. It makes a quick groundcover in dampish, light soils. But, wherever sarmentosum can be given a real chance, it proves a most beautiful thing. Start a piece of it off by the side of a brook tumbling down a hill-side and you will reap so beautiful a cascade of lush, green, streaming foliage, with a glint of golden flowers in it, that you will gasp at the wonder of it.-Sarmentosum wants only a little water, a little sun, a little soil and a hillside.

The rock garden is not to be thought of as primarily a flower garden. It has but one great burst of bloom,-in the spring 


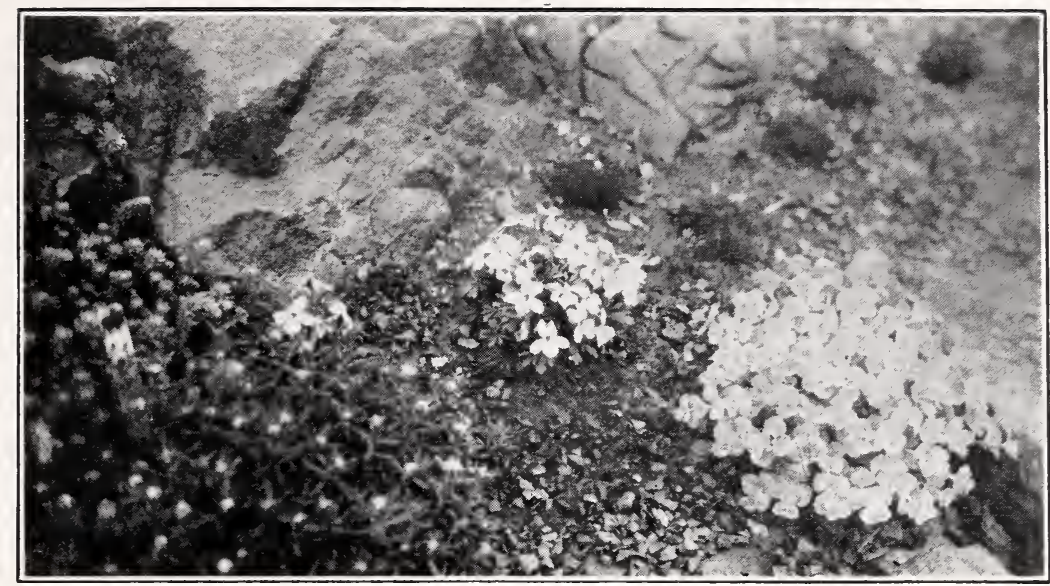

Right, Sedum sieboldi. Center, a bit of Birdsfoot Violet.

sexangulare is practically a showier form of acre, differing from acre mainly in that the little leaves are linear, while those of acre are broadest at the base. A very pretty thing for shallow, poor soil.

sieboldi. A very fine Japanese species, which radiates 5 to 7 -inch stems, fountain-fashion, from a perennial base. It is not evergreen. The leaves are fleshy, gray, the size of a nickle, roundish, edged with carmine in open sunny places; -all gray in darker places. Very pretty, bright carmine flowerheads in September or October.

sieboldi variegatum. A showy form of sieboldi with a blotch of golden-yellow on each leaf.

spectabile, dwarf form. This is just a much smaller form of the familiar Showy Stonecrop. Not over one foot high, with somewhat deeper rose flower heads.

spurium. Running Stonecrop. A rapid-spreading evergreen plant, serviceable as a groundcover for larger areas. It bears light rose flowerhaeds in July, well above the foliage. It is not as desirable a ground-cover plant as the variety coccineum.

spurium album. A white-flowering form, not particularly showy in bloom. 'This form was formerly called S. oppositifolium. "Standardized Plant Names" contains this name and calls it a "Two-row Stonecrop", which it is not in any particular sense. 

crop. It bears dark-rose flowerheads in July and has better foliage than the type. The foliage assumes attractive reddish shades toward winter. It is a very fine groundcover plant, deserving of wide use.

stenopetalum. A small, inconspicuous, slow-growing Western plant, scarce $1 \mathrm{I} / 2$ inch high in leaf, rather erect of habit, with green, linear leaves and inclined to purplish winter shades. In late May or in June it sends up a surprisingly fine display of golden-yellow flower cymes, with long, rather erect prongs. An exceptionally fine thing in bloom and so unobtrusive a little plant for the rest of the year, that it should indeed be freely used in the rock garden. It is an easy plant in sunny, light soil.

stoloniferum. 'This is a creeping Sedum with reddish stems and puslane-like foliage, with light-rose flowerheads in June or July, much like those of spurium (type). The name is often, as in "Standardized Plant Names", confused with that of spurium. Stoloniferum is quite distinct from it. It has weaker, reddish stems and does not winter as well as spurium, coming through our winters, usually, in a somewhat battered condition. It seeds itself very freely in the garden, much more so than spurium. It is rather a pretty patch of lush-looking foliage, when wellgrown, but not as useful a Sedum as spurium. It likes a light, dampish soil.

stribrnyi. Under this strenuous name goes a small, modest plant which might be taken for a small, grayishgreen form of reflexum, in leaf. In June, however, there rises a very fine display of long, rather erect flower prongs with lovely, soft-yellow flowers, up to 6 inches high. A very pretty and pleasing little plant for sunny, light soils.

ternatum. This woodland Sedum grows wild, hereabout. It makes dense mats of dull-green foliage, with rather frail and brittle stems, topped in May with a lovely display of fuzzy, white flowerheads, with black anthers. A charming thing for shady places, in an acid, woodsy soil. It is the first of the Seda to bloom. 


\section{SEMPERVIVUM. Houseleek. Hen-and-Chicks.}

Those of the following species marked (*), following the names, are offered with some surety of their being true to name. All others are offered without any guarantee of their being correctly named.

For best effects in the garden, we recommend that only the smallest forms, - particularly arachnoideum and fauconnetti, be used in very shallow soils or planted on rough rock surfaces. All of the larger or medium-large forms will thrive better and be more effective if set in reasonably deep soils, not too poor. Especially the largest forms are grateful for a well-prepared, fairly rich, deep, porous soil. The smaller forms may be left undivided and will form pretty, tight colonies. It is better to separate the colonies of larger plants from time to time. They lose their best characteristics when left crowded and starved.

arachnoideum (*) The Cobweb. Gray, small rosettes, covered with white webbing. It flowers sparingly, with truly fine, ruby-red stars, on slender stems.

arenarium. Small, bright green, starry rosettes, hairy and closely matted. Short flower stems, topped with pale yellow flowers which do not open widely, but are rather pretty.

brauni. Small rosettes, up to $1 \frac{1}{2}$-inch wide, formed like a tectorum, bronze-green, with quite robust stems and dull, greenish-rose flowers.

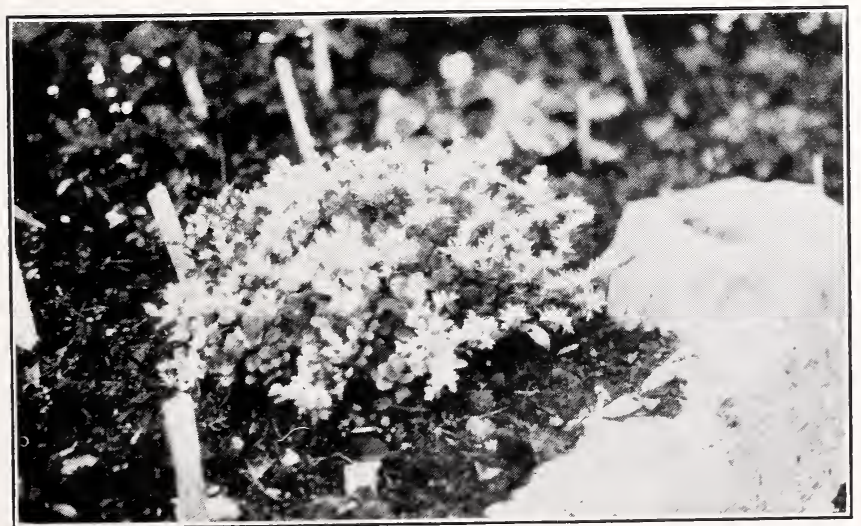


calcareum (*). 'This is S. californicum of "Stand. Plant Names." Distinct, pale-blue-green rosettes, much inclined to grow one-sided,-high on one side. The leaves are tipped dark brown. It makes short runners, which means crowded-looking colonies.

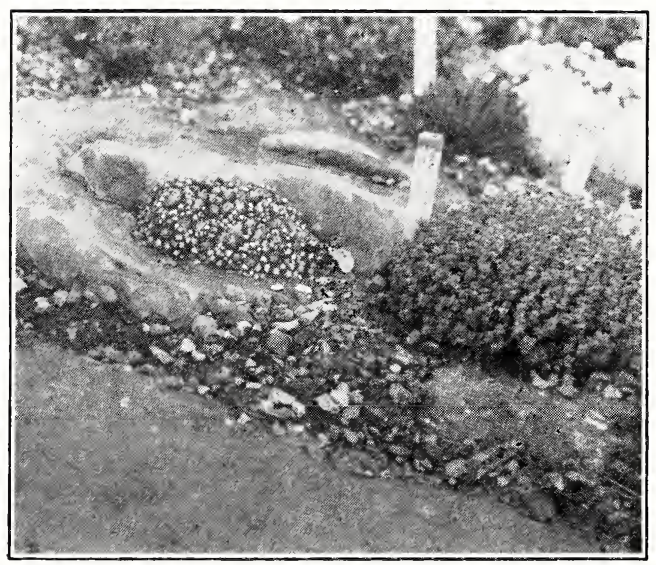

Left, Sempervivum fauconnetti, growing on a bare stone surface. Right, Sedum dasyphyllum, getting ready to flower.

fauconnetti (*). The form which we raised from seed is the prize-winner of our assortment. In deeper soil it makes rosettes as large as $3 / 4$-inch, but in very shallow soil or on stone surfaces it forms dense mats of very tiny rosettes, $1 / 8$-inch wide. These mats are very beautiful. The tiny leaves are green, tipped red and the rosette is somewhat webby. It is the most striking and most coveted of our Semperviva. It establishes itself with surprising ease on the most inhospitable stone-surfaces.

funcki. A small, well filled, green rosette, which retains a good green color at all times, blooms freely and bears dull-rose flowers on robust, 6 to 8 inch stems. The rosettes grow $3 / 4$ to 1 inch wide.

la harpei (*). A tectorum-like rosette, with purplish. shadings, deeper toward the center. It is a whopper for size. We have had them grow 8 inches wide. It sends up robust stems with the lamentable dull-rose flowers so common amongst Semperviva. A very decorative, large plant.

mettenianum (*). This is another, immense tectorum with peculiarly pale, bluish-green leafage and with the center of the rosette quite closed over, white-cabbage style. 
pittoni (*). A medium-size rosette, grayish green and

quite hairy. It forms pretty, tight patches and sends up

6 to 7 -inch stems topped with greenish-yellow stars. It is very good Sempervivum.

regia-amaliae (*). This is a rather rare, good plant. It makes sparse-leaved rosettes, rather irregular, with long, somewhat erect, pointed, downy leaves and it bears a somewhat drooping roundish head of pale-yellow bellshaped flowers, in late July or August. The young rosettes are formed in the axils of the old rosettes, which results in very crowded, huddled colonies. It propagates slowly and sparingly.

rubicundum as we have it is a truly lovely thing. Grayish, downy rosettes, suffused with purple, sparseleaved and with long, leafy runners.

rubicundum hybridum in our garden is the brightestcolored of all. Stiff, medium sized, bright-green-and-red leaves. A very showy and distinct thing.

seedling Sixty. (*) 'Th.s showy and decorative seedling orignated in a Poughkeepsie garden. It makes large, hairy rosettes of green and maroon-red, well filled and yet of a graceful appearance. It bears the offsets on long runners. A clump set in a high place, with the runners stretching out and gripping the edge of a rock, makes a striking, somewhat spidery efiect.

We take particular pride in popularizing little-known plants of exceptional merit

There are ever so many little-known piants of far greater value in and about the rock garden than many which occur in catalogs and planting lists with pious regularity

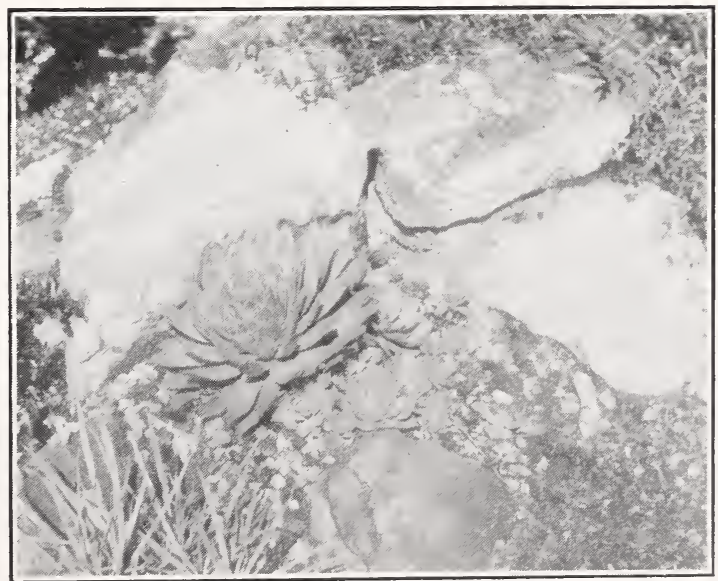

Sempervivum la harpei, a very large and impressive rosette. 
soboliferum or globiferum. We know not which is which. The plant we offer makes thick patches of brightgreen, balled rosettes, with the youngsters appearing all over the surface of the old ones, attached by thin threads, which soon break and send the chickies rolling and rooting all over the lot. In extreme drought or cold exposure the rosettes turn reddish outside. We have never known this form to bloom. The oldest rosette we had, which had become quite open, upon analysis, showed no embryonic formation of any flowering parts. It makes a good furnishing plant and propagates faster than any other.

tectorum $(*)$. To this venerable plant humanity is, indeed, indebted. Besides having furnished our gardens with most of its Sempervivum forms, it has, according to popular lore, cured the sores of past generations and warded off lightning from their roofs. It has never been settled whether it is, originally, a fallen artichoke or a dissatisfied Nymphea, punished for its yearning to explore the dry land. Be that as it may, tectorum is a most impressive, large, dull-green rosette and makes large patches, from which rise sturdy, leafy stalks with dull-rose flowers.

triste (*) is patterned after tectorum and executed in a most doleful shade of maroon-red. It grows large and sends up a mighty flower stalk, with leaves and flowers all in the same mournful hue. A most distinct and conspicuous thing, but perhaps of a weaker constitution than most Semperviva and best kept sheltered from the most trying sunshine. It has a tendency to wilt in very hot sun.

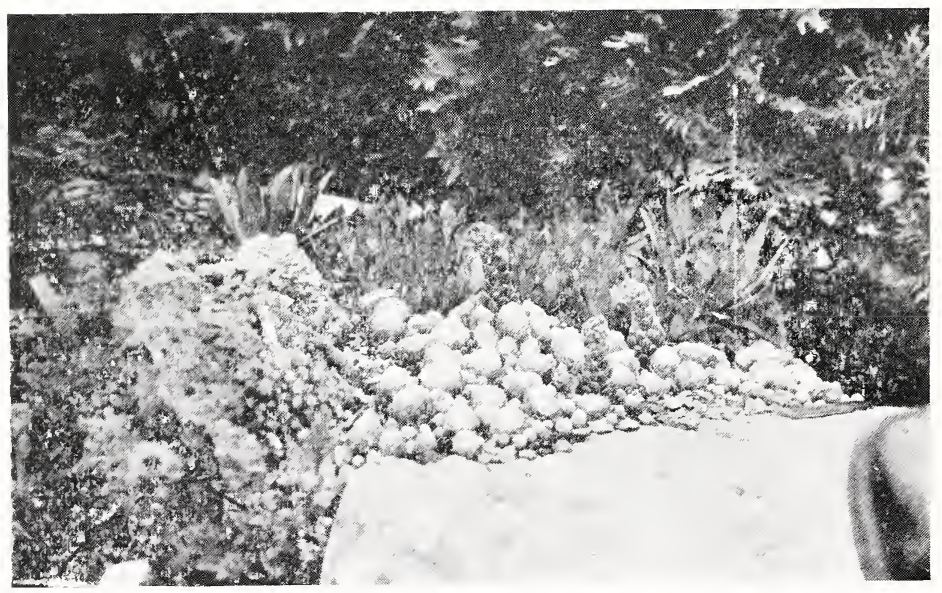

Top. Sempervivum t r iste. F o r e g round, the Cobweb Sempervivum. Growing on tufa, $\mathrm{S}$. f a u co nne t t i. 
Here are two beautiful, gray spreads for the rock garden,- -little-known and rarely used: Veronica pectinata and Antennaria neodioica.

Here is a flowering ground-cover plant of exceptional merit;-quickly-spreading, evergreen, durable and pretty of flower and of foliage: Veronica filiformis

SENECIO tyrolensis. 'This makes a very pretty, compact clump of deep green, finely-cut foliage, for moist, sunny spots. It has bright-orange colored flowersheads in July.

SILENE alpestris makes dense masses of low, green folliage, from which rises a fine spread of pure white flowers on 6 to 8 inch stems, in May or early June. A very effective clump,--the flowers sometimes fading to pale pink. We grow it in a sunny, well-drained soil.

SILENE schafta. A good, low, tidy clump with rose-pink flowers in early fall.

SYMPHYANDRA Hoffmanni. A Campanula-like plant with 18-inch spikes of white bell-flowers. It may be treated like a Campanula and likes a shady, cool spot in the rock garden.

TEUCRIUM chamaedrys. A very good, evergreen, low, matting plant with deep green, glossy, toothed leaves. These mats are topped, in July, with short, dense spikes of purplish-rose flowers, about 6 inches high. It is easily grown in sunny or shaded places and makes a fine evergreen mat.

canadense looks very much like an upright, shrubby form of it, which, here, grows about 15 inches high. In sheltered places it retains its foliage all winter. A very fine little shrub for the rock garden. It has deeper rose flowers, scattered thinly along the upright stems.

There is a great wealth of little-known rock garden plants, - of first-rate plants that are rarely used.

Many of these valuable, little-known plants may be seen growing in our trial gardens, which are open six days a week 


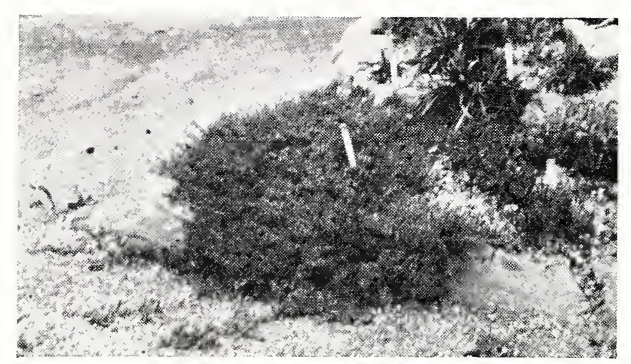

A mat of Thymus serpyllum, Creeping Thyme.

Page THYMUS citriodorus aureo var. This is a bushy plant 52

with a rather woody, decumbent base. The leaves, especially in late summer and fall, are brightly colored, yellow and green.

herba-barona is a variable species, of which we offer a trailing form. The species is distinguished by its marked anise-smell,--very distinct from the flavor of serpyllum. serpylum. Creeping Thyme. A very variable plant. The for $\mathrm{m}$ we grow mainly makes a beautiful evergreen, thick groundcover, less than 2 inches high, topped in July with erect flower heads of pale rosy purple. A very useful gioundcover for poor soils.

serpyllum album is a striking, light, bright-green, very small-leaved groundcover which blooms white, in July. The flowerheads are not borne on erect stems, but laid low over the plants. A very lovely, charming thing in bloom.

serpy ium, aureo var. This is a low, trailing form with biight yellow-variegated leaves most showy in the fall.

serpyllum deep rose. This is a beautiful, tiny-leaved form with brilliant, deep rose flowerheads in June or July. Altogether a smaller thing than serpyllum type and very fine as a paving plant.

Exrpyinum lanuginosus. Woolly Thyme. A lovely gray, hairy mat. A most charming thing when wellestablished. It makes a fine, fragrant paving plant. It is best planted cool, away from the hottest sun, so as to avoid sunburn.

serpyllum, large-leaved form. A remarkable seedling form we raised. It has very long, narrow leaves, almost like those of a Helianthemum. It is a rampant spreader and very showy in bloom, in June, with erect, large flower-heads of a lovely, pale lilac shade.

serpy Illum, silver-variegated. This is not a trailer, but rather a bush, with a decumbent base. It grows up to 6 inches high, with pretty, white and green foliage. 
vu'garis is as finely scented as any. It is a shrubby, Page woody plant, with a heavy, woody, decumbent base and 53 the stems rising rather erect. It is grayish-green and bears pale lilac-purple spikes in June or July. A very effective plant when well-used. It is suggestive of heather in its effect and looks well when planted with heather.

Woolly Thyme. Thymus serpyllum lanuginosus. One of the choicest bits of drapery in the rock garden

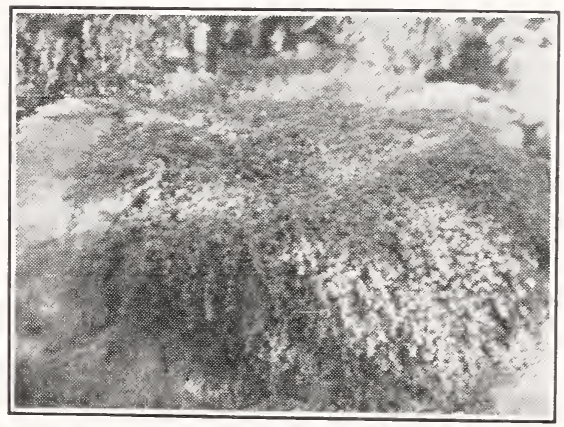

TSUGA canadensis pendula. Sargent Weeping Hemlock. These will, eventually, make large, low, broad specimens and should be used only in the larger rock gardens. They are very beautiful, rare evergreens. The late Prof. Sargent discovered this form of Hemlock in the Hudson Highlands.

UMB LICUS chrysanthus is practically a Sempervirum. It makes quickly spreading, dense mats of gray, hairy rosettes, with whitish-yellow flowers. It makes very pretty masses.

VALERIANA montana is a tiny, neat, tufted plant, 1 or 2 inches high, with white flowerheads in May, on $t$ inch stems. It wants a cool, well-drained place.

Plants with grayish, woolly foliage are, as a rule, sensitive to moisture about the foliage and require sharp drainage.

When spring is gone, the rock garden 's largely a plant-sanctuary; - a garden of plant associations, of cushions and mounds and blankets f foliage.

Flower is important, but spring is short and it is wise to consider the more permanent values of plants in the rock sarder. 
VERONICA alioni is a prostrate mat of creeping stems, set with bright green, glossy, oval leaves which lie flat on the ground. It does not bloom very freely but makes a fine paving plant. It wants a loamy soil and a cool place.

See

Illustration

Page 56

armena. This is a little-known Veronica of outstanding merit. It makes low mats of deep-green, palmately divided foliage, from which, in May, rise short, graceful sprays of gentian-blue flowers. 'There is a fine, airy, transparent quality about this show which sets armena quite apart from other Veronicas. It wants a light, gritty, sunny spot. filifolia. Under this uncertain name we carry a beautiful, uncommon Veronica which makes a broad, low mass of deeply cut foliage, from which rises, in May, a showy spread of erect flower spikes carrying white flowers. In summer, the plant makes a good mass of deep green, graceful foliage. The flower stems rise about 8 inches high.

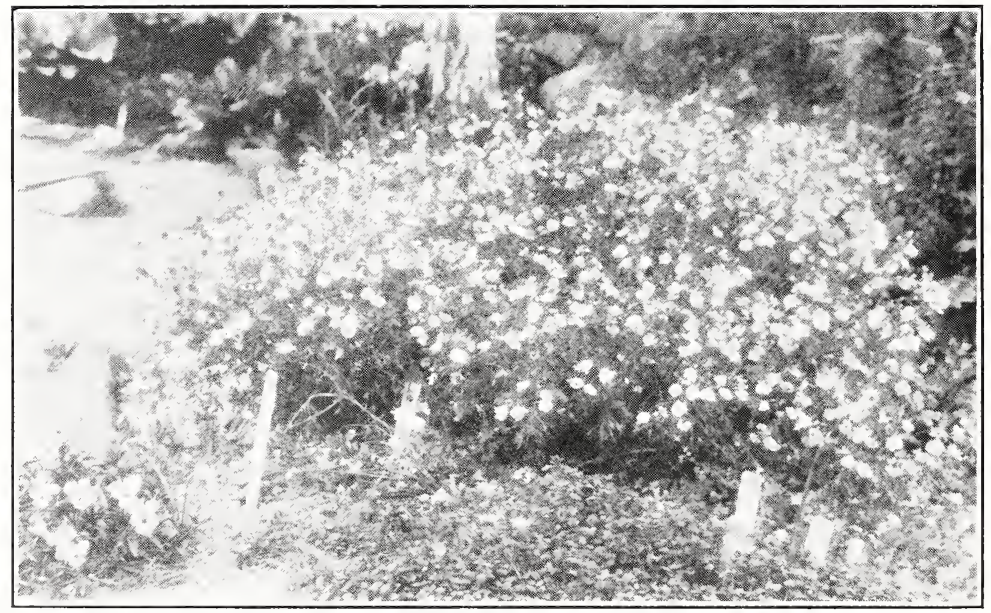

Veronica filifolia

filiformis is an evergreen flowering groundcover of the greatest value. It makes rich, fluffy masses of light-green foliage;--small, rounded leaves on thread-fine stems. These mats grow from two to three inches thick and they are liberally sprinkled in April or May with small, starry, white-and-china-blue flowers, on very dainty, airy stems. It grows incredibly fast and it roots very readily; every bit of it pulled up and thrown over the fence takes root promptly. 


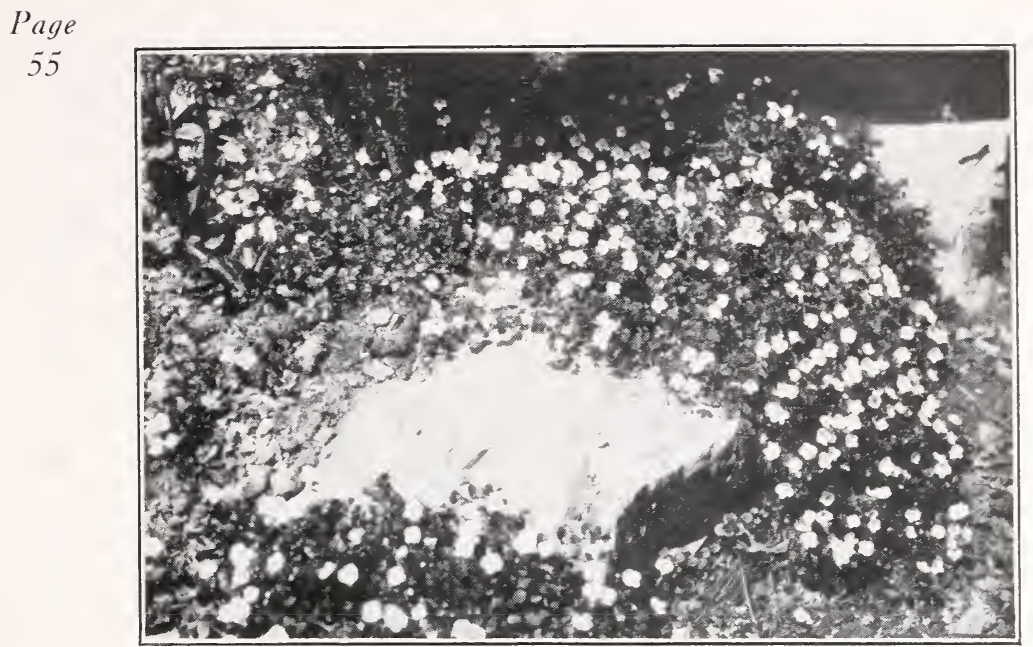

Above-Veronica filiformis, in bloom.

It is a pretty looking mat and retains its foliage in fine condition through the winter. In this respect it is a much more valuable groundover plant than, for instance, Mazus rugosus. When it is finished flowering, you may run the lawn-mower over the mats and keep them short and flat, if that is desired.

This plant wants to be used in light soil which does not become utterly parched in summer. Only in extreme, dry, parching sunshine does the foliage sometimes burn. Veronica filiformis is a most delightful and beautiful flowering groundcover and should be used widely.

Below-Veronica filiform: one of the prettiest of flo w e ring cover-plants, used amongst evergreens.

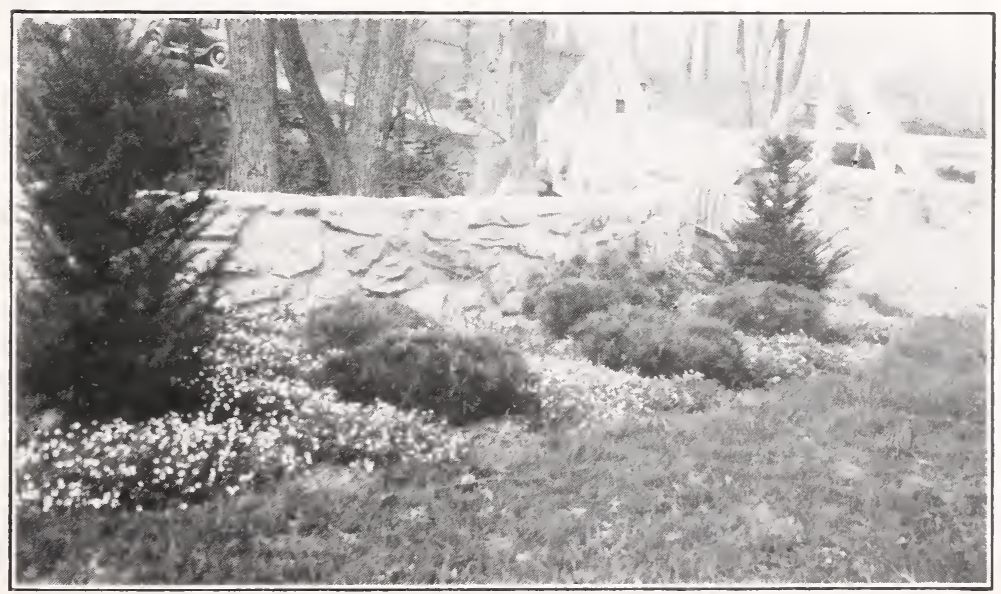




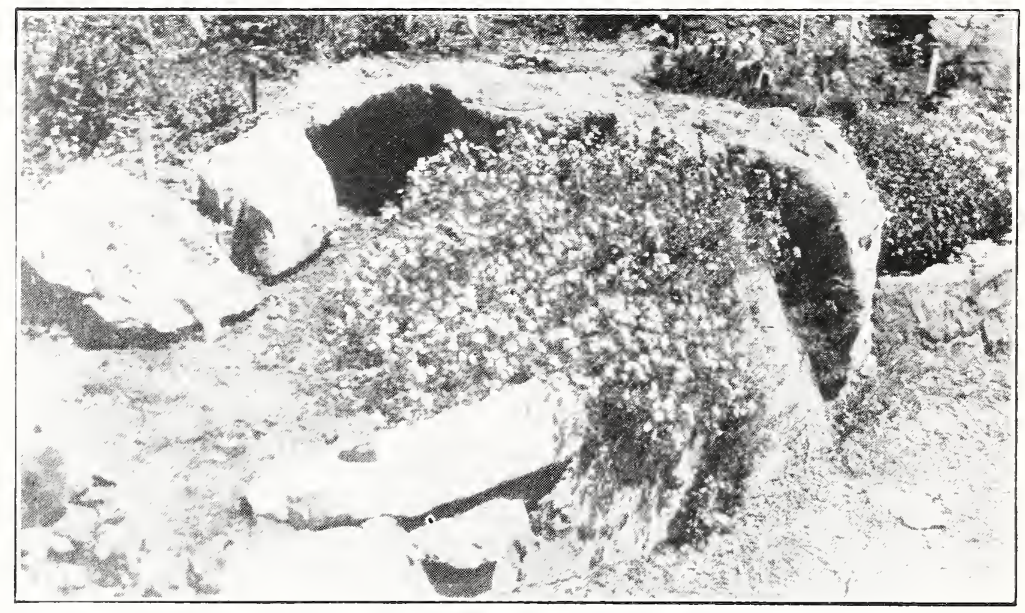

This picture does but scant justice to Veronica armena. The plant snculd be seen in cur trial garden.

gentianoides is a distinct plant with bright-green, short, tufted foliage, from which spring very tall, spiry spikes of blue flowers in May. It wants a fairly rich loam.

incana. This is a neat, tufted clump of gray foliage, a few inches high, from which rise, in July, stately, erect spikes, up to 15 inches high, with rich royal blue flowers. It is a noble plant for the rock garden, common as it is. It likes a dry, well drained soil.

nummularia makes a one-inch-high mat of evergreen foliage on very short, erect stems. It bears deep blue flowers, scarcely above the foliage, in June. It is a slowspreading, choice plant and quite rare. For gritty soil, in open or lightly shaded spots, with some humus in the soil.

pectinata, rose flowering. Pectinata makes a magnificent, gray, woolly mat, an inch high. It is a very beautiful thing, spreads rapidly and, at first sight, puts one in mind of a very coarse mat of Woolly 'Thyme. Only, the foliage is a lighter gray and larger. It makes a fine effect when it trails down over the rocks and often forms into thick wads. Bright-rose, little flower spikes appear in June, peering through the foliage, but not rising rising above it. It wants a dry, gritty, well-drained, sunny spot and may be recommended as a beautiful thing for the rock garden.

pectinata, blue flowering. This is a form with Page bright blue flower heads, instead of rose. Both forms are equally vigorous and identical in foliage and habit. 
repens is a tiny creeper with very small, green leaves,

which is a most excellent paving plant if it can be given a rather rich loam, some moisture in the soil and kept out of the most parching sunlight. It will go out in very hot exposures, in summer. It is hardly $1 / 4$ inch high, with flowers of palest blue, set flat upon the foliage.

saxatyle makes an evergreen mat scarcely an inch high; -a very good-looking, dark-green, slow-spreading mat. It sends up flower stems, about a foot high, in May;thin spikes of blue flowers which fall just short of being showy. They open a few at a time and last only a day and open only in sunny weather. Cut the flower stems away as soon as practicable and you will have a fine evergreen mat in the garden, which is good all the year around.

saxatyle alba is a white flowering form of this, identical in appearance, except for a lighter green tint of foliage. It is perhaps somewhat showier in bloom. Both forms want a well-drained, gritty soil, with humus in it, and prefer very light shade.

spicata corymbosa (spicata alpina) is a very neat little tuft of green, roughish foliage, an inch or so high, from which rise spikes, in July, which imitate those of incana but do not quite reach that stature or magnificent blue. Cut the flower stems early and you will have a very fine tuft of green. It wants a well-drained, gritty soil and sun.

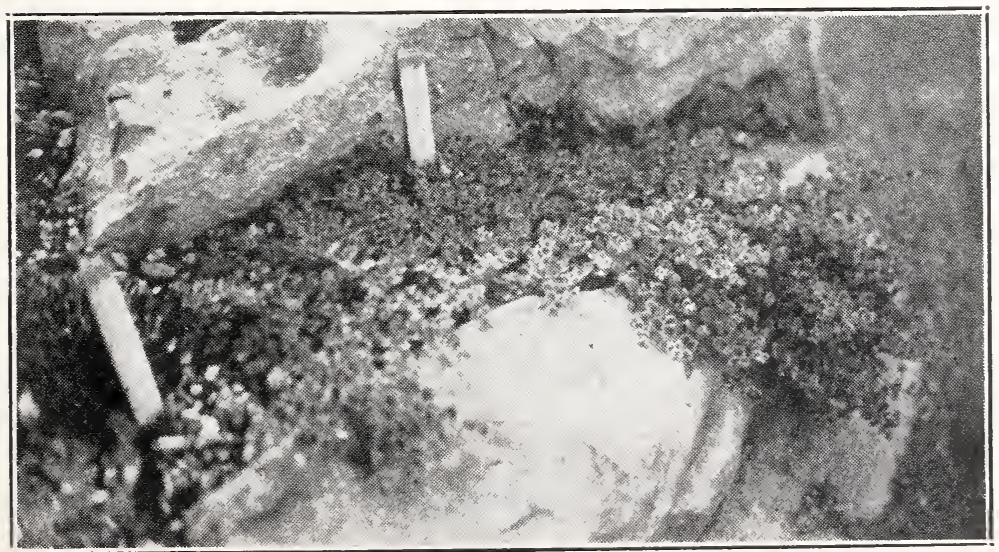

Veronica pectinata makes beautiful blankets and wads of gray, woolly foliage in the garden. 
teucrium rupestre is a rampant, beautiful trailer with good, dark green foliage and short spikes in spring, of rich purplish-blue flowers. It is very showy, very easy to grow and best used where it may be seen tumbling down from some height.

teucrium rupestre alba as we have it is a much less robust plant with lighter green foliage, from which rise spikes of dazzling-white flowers in the spring. It is a beautiful thing and worthy of use in the rock garden. It is a finer, daintier thing than rupestre type.

teucrium rupestre rosea is also less robust than the type. It has narrower, deeper green foliage and the spikes are quite a good pink. A pretty plant.

teucrium rupestre trehani makes a pretty, occasional splash of bright golden foliage; - a solid little mat, two or three inches high, pretty enough in leaf, but with bright blue spikes which contrast rather harshly with the foliage.

VINCA alpina, as we have it, is very like the common Periwinkle, except that the flowers are reddish violet, not brilliant, but of a soft shade and very pretty.

herbacea is a Periwinkle which sends out long runners which root at the tips and dies down above ground in winter. It has very preety, light lavender flowers with narrow petals.

VIOLA odorata alba is the white flowering fragrant Violet and a very pretty thing in the spring.

Princess of Wales is a single, blue, Sweet Violet.

Mrs. David Lloyd George is a semi-double variety. Jersey Gem is a very fine bedding Viola, perhaps too gardenesque for the rock garden. It blooms persistently and freely, all summer.

rugulosa is a robust species which bears cheerful little pale pink flowers on strong, leafy stems. It is a very pretty thing to tuck away under a bush where its cheery little flowers may peer out at you for a while in the spring. It is rather too weedy to use any other way in the rock garden.

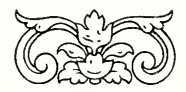




\section{ROCK GARDEN MEMORANDUM}


ROCK GARDEN MEMORANDUM 
ROCK GARDEN MEMORANDUM 
ROCK GARDEN MEMORANDUM 


\title{
Other Things
}

\section{Besides Rock Plants}

\section{You will find at our nursery}

All The Furnishings For The

\author{
OUTDOOR LIVING ROOM \\ FLOWER GARDEN \\ HOUSE FRONT \\ BOUNDARY PLANTING
}

Evergreens For All Purposes

SARGENT WEEPING HEMLOCK ARBORVITAE

HEMLOCK

HINOKI CYPRESS

Etc.

Choice Eo Rare Shrubs

\section{NEW BARBERRIES \\ EUONYMUS ALATUS DWARF BEAUTY BUSH}

Etc.

Trees

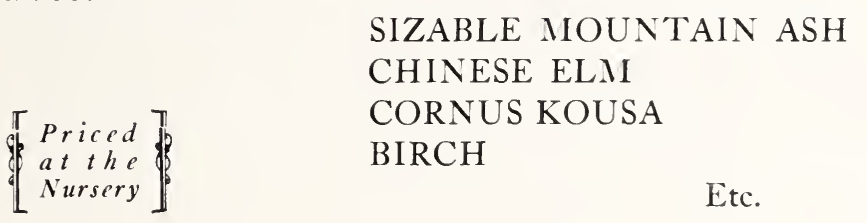

Poughkeepsie Nursery Company, Inc.

Box 278

POUGHKEEPSIE, N. Y. 
Designed by Rhincbeck Mail-Ad Service

Printed by Livingston Press-Livingston, N. Y. 


\section{ORDER BLANK \\ Poughkeepsie Nursery Company, Inc.}

Poughkeepsie, New York

P. O. Box 278

Date

Name

Street Address

City

State

Remittance enclosed, \$

Do you wish all plants ready now to be shipped at once?

If not, on or about what date shall we ship?

Note-Please read carefully the information on pages 2 and 3 of our catalogue.

Five-rates apply to from three to nine plants of any one listing. Ten-rates apply to from ten to twenty-four plants of any one listing. For single plants, or two of a kind, add five cents per plant to the five rate.

\begin{tabular}{|c|c|c|c|c|c|}
\hline Quan & & $\begin{array}{c}5 \\
\text { Rate }\end{array}$ & $\begin{array}{c}10 \\
\text { Rate }\end{array}$ & $\begin{array}{c}100 \\
\text { Rate }\end{array}$ & Total \\
\hline & Acaena cylindrostachys & .40 & .35 & & \\
\hline & buchanani ........ & .50 & .45 & .40 & \\
\hline & Achillea ageratifolia . . & .40 & & & \\
\hline & argentea $\ldots \ldots$ & .50 & .45 & . & \\
\hline & nana $\ldots \ldots \ldots$ & .35 & .30 & & \\
\hline & tomentosa ..... & .40 & .35 & .30 & \\
\hline & tomentosa alba .. & .40 & .35 & .30 & \\
\hline & Aethionema, seedlings & .50 & .45 & .40 & \\
\hline & Ajuga genevensis .... & .40 & .35 & .30 & \\
\hline & Alchemilla alpina ... & .50 & & $\ldots \ldots$ & \\
\hline & Alyssum rostratum .. & .40 & .35 & & \\
\hline
\end{tabular}


Amount carried over \$

\begin{tabular}{|c|c|c|c|c|c|}
\hline Quan. & & $\begin{array}{c}5 \\
\text { Rate }\end{array}$ & $\begin{array}{c}10 \\
\text { Rate }\end{array}$ & \begin{tabular}{c|}
100 \\
Rate
\end{tabular} & Total \\
\hline & saxatyle compactum ........ & .35 & .30 & .25 & \\
\hline & montanum $\ldots \ldots \ldots \ldots$ & .45 & & & \\
\hline & Anchusa myosotidiflora & .50 & .45 & & \\
\hline & Anrosace carnea brigantiaca .... & .75 & & & \\
\hline & sarmentosa $\ldots \ldots \ldots$ & .60 & .55 & .50 & \\
\hline & sarment. chumbyi ......... & .60 & & & \\
\hline & sarment. watkinsi ......... & .60 & & & \\
\hline & lactiflora $\ldots \ldots \ldots \ldots$ & .40 & .35 & & \\
\hline & Antennaria neodioica ..... & .40 & .35 & 30 & \\
\hline & rhodantha $\ldots \ldots \ldots \ldots \ldots$ & .40 & .35 & .30 & \\
\hline & Anthericum lilastrum majus ... . . . & .60 & & & \\
\hline & Aquilegia alpina $\ldots \ldots \ldots \ldots \ldots$ & .40 & .35 & .30 & \\
\hline & coerulea $\ldots \ldots \ldots \ldots \ldots$ & .35 & .30 & 25 & \\
\hline & flabellata nana $\ldots \ldots \ldots \ldots$ & .35 & .30 & 25 & \\
\hline & Arabis albida ......... & .35 & .30 & .25 & \\
\hline & albida flore pleno ........... & .40 & .35 & .30 & \\
\hline & kellereri . . . . . . . . & .60 & .55 & & \\
\hline & mollis $\ldots \ldots \ldots \ldots \ldots$ & .40 & .35 & .30 & \\
\hline & Arenaria verna caespitosa $\ldots \ldots \ldots$ & .40 & .35 & .30 & \\
\hline & Armeria cephalotes $\ldots \ldots \ldots \ldots$ & .35 & .30 & 1 & \\
\hline & cupluroides ... & .75 & & & \\
\hline & laucheana $\ldots \ldots \ldots \ldots \ldots$ & .35 & .30 & 25 & \\
\hline & maritima alba $\ldots \ldots \ldots \ldots \ldots$ & .45 & & & \\
\hline & maritima $\ldots \ldots \ldots \ldots \ldots$ & .35 & .30 & .25 & \\
\hline & Six Hills hybrid ......... & 1.00 & .90 & & \\
\hline & Asperula odorata $\ldots \ldots \ldots \ldots \ldots$ & .40 & .35 & .30 & \\
\hline & Aster subcoeruleus $\ldots \ldots \ldots \ldots \ldots$ & .40 & & & \\
\hline & farreri $\ldots \ldots \ldots$ & .60 & .55 & & \\
\hline & mauve cushion $\ldots \ldots \ldots \ldots$ & .35 & .30 & & \\
\hline & Aubretia, seedlings $\ldots \ldots \ldots \ldots$ & .35 & .30 & .25 & \\
\hline & Berberis julianae ............ & 1.75 & 1.50 & 1.40 & \\
\hline & verruculosa, $18-20$ inches $\ldots$. & 4.50 & 4.00 & & \\
\hline & buxifolia nana $\ldots \ldots \ldots \ldots$ & 1.10 & 1.00 & .90 & \\
\hline & buxifolia pygmea ........... & 1.10 & 1.00 & .90 & \\
\hline & Bellium minutum $\ldots \ldots \ldots \ldots$ & .50 & .45 & .40 & \\
\hline & Bruckenthalia spiculifolia ..... & 1.00 & .90 & .85 & \\
\hline & Campanula bellardi ............ & .60 & $\ldots$ & $\ldots$ & \\
\hline & portenschlageana $\ldots \ldots \ldots \ldots$ & .40 & .35 & .30 & \\
\hline & raddiana $\ldots \ldots \ldots \ldots \ldots$ & 60 & .55 & & \\
\hline & scheuchzeri $\ldots \ldots \ldots \ldots \ldots$ & .40 & .35 & & \\
\hline
\end{tabular}


Amount carried over \$

\begin{tabular}{|c|c|c|c|c|c|}
\hline Quan. & & $\begin{array}{c}5 \\
\text { Rate }\end{array}$ & $\begin{array}{c}10 \\
\text { Rate }\end{array}$ & $\begin{array}{c}100 \\
\text { Rate }\end{array}$ & Total \\
\hline & Cerastium tomentosum ........ & .35 & .30 & .25 & \\
\hline & thomassi $\ldots \ldots \ldots \ldots \ldots$ & .50 & & & \\
\hline & Chamaecyparis obtusa compacta & 4.00 & 3.75 & & \\
\hline & Chrysanthemum arcticum ....... & .35 & .30 & .25 & \\
\hline & Cornus canadensis $\ldots \ldots \ldots \ldots$ & .50 & .45 & .40 & \\
\hline & Corydalis cheilanthifolia .. & .60 & & & \\
\hline & bulbosa $\ldots \ldots \ldots \ldots$ & 60 & & & \\
\hline & lutea $\ldots \ldots \ldots \ldots \ldots$ & .60 & & & \\
\hline & Cotoneaster microphylla ....... & 2.25 & 2.00 & & \\
\hline & horizontalis perpusilla .... & 1.65 & 1.50 & & \\
\hline & Cotula squallida $\ldots \ldots \ldots$. & .45 & .40 & .35 & \\
\hline & Dianthus alpinus ..... & .60 & .55 & & \\
\hline & alpinus $X$ superbus & 2.00 & & & \\
\hline & caesius arvernensis . . . . . . & .45 & 40 & .35 & \\
\hline & knappi . . . . . . . . . & .45 & 40 & & \\
\hline & Dodecatheon radicatum & .45 & .40 & & \\
\hline & Draba androsace ...... & .50 & .45 & 40 & \\
\hline & kutschyi ... & .70 & .65 & .60 & \\
\hline & olympica. & .75 & & & \\
\hline & repens $\ldots \ldots \ldots \ldots \ldots$ & .50 & .45 & & \\
\hline & Dryas cotopetale $\ldots \ldots \ldots \ldots$ & .75 & & & \\
\hline & sundermanni $\ldots \ldots \ldots \ldots$ & .75 & & & \\
\hline & Epilobium nummularifolium ... & .60 & .55 & .50 & \\
\hline & Erigeron mesa-grande speciosus & .40 & 35 & .30 & \\
\hline & Erinus alpinus $\ldots \ldots \ldots \ldots \ldots$ & .45 & 40 & & \\
\hline & Euonymus radicans minimus ... & .70 & 65 & .60 & \\
\hline & Galax aphylla $\ldots \ldots \ldots \ldots$ & .50 & $\cdots$ & & \\
\hline & Gaultheria procumbens ....... & .50 & .45 & .40 & \\
\hline & Genista-sagittalis $\ldots \ldots \ldots \ldots$ & .65 & 60 & & \\
\hline & Gentiana acaulis ...... & 1.00 & .90 & & \\
\hline & Geranium pyzlowianum & 1.00 & .90 & & \\
\hline & Geum montanum ..... & .60 & 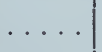 & & \\
\hline & triflorum $\ldots \ldots \ldots$ & .50 & & & \\
\hline & Globularia cordifolia ..... & .60 & & & \\
\hline & nudicaule $\ldots \ldots \ldots$ & .60 & .55 & .50 & \\
\hline & trichosantha ... & .50 & .45 & & \\
\hline & Hedera minima ....... & .75 & & & \\
\hline & Helianthemum, seedlings & .35 & .30 & .25 & \\
\hline & Herniaria glabra .......... & .40 & .35 & .30 & \\
\hline & Heuchera briz. Plui de Feu ..... & .45 & .40 & .35 & \\
\hline
\end{tabular}


Amount carried over \$

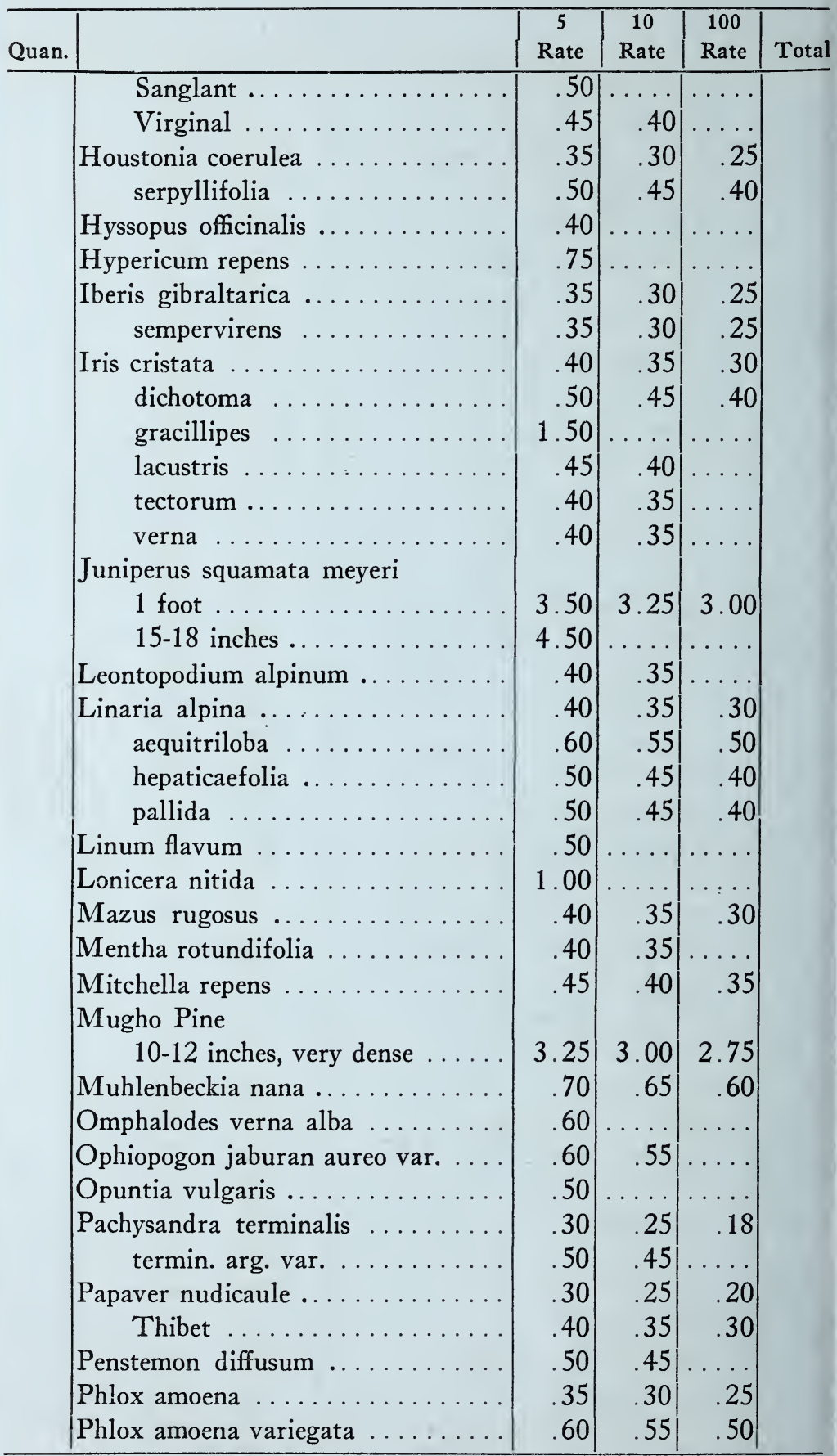

Total \$ 
Amount carried over \$

\begin{tabular}{|c|c|c|c|c|c|}
\hline Quan. & & $\begin{array}{c}5 \\
\text { Rate }\end{array}$ & $\begin{array}{c}10 \\
\text { Rate }\end{array}$ & $\begin{array}{c}100 \\
\text { Rate }\end{array}$ & Total \\
\hline & canadensis (divaricata) $\ldots$ & .35 & .30 & .25 & \\
\hline & canadensis laphami ........ & .40 & .35 & 30 & \\
\hline & canadensis alba $\ldots \ldots \ldots \ldots$ & 40. & .35 & & \\
\hline & ovata (carolina) .......... & .35 & .30 & & \\
\hline & pilosa splendens $\ldots \ldots \ldots \ldots \ldots$ & 40 & $\cdots$ & & \\
\hline & procumbens $\ldots \ldots \ldots \ldots \ldots$ & 40 & .35 & 30 & \\
\hline & reptans (stolonifera) ....... & .40 & .35 & 30 & \\
\hline & subulata alba $\ldots \ldots \ldots \ldots \ldots$ & .35 & .30 & 25 & \\
\hline & lilacina $\ldots \ldots \ldots \ldots$ & .35 & .30 & 2.5 & \\
\hline & Vivid $\ldots \ldots \ldots \ldots \ldots$ & .45 & .40 & .35 & \\
\hline & Phyteuma scheuchzeri ......... & .45 & .40 & & \\
\hline & Polemonium pulcherrimum ...... & .45 & .40 & & \\
\hline & reptans $\ldots \ldots \ldots \ldots \ldots$ & .45 & 40 & & \\
\hline & Potentilla alba ............. & .45 & & & \\
\hline & aurea $\ldots \ldots \ldots \ldots \ldots$ & .45 & .40 & .35 & \\
\hline & rupestris pygmea $\ldots \ldots \ldots \ldots$ & .45 & .40 & .35 & \\
\hline & tonguei $\ldots \ldots \ldots \ldots \ldots \ldots$ & .75 & .70 & & \\
\hline & tridentata $\ldots \ldots \ldots \ldots \ldots$ & .45 & .40 & & \\
\hline & verna nana $\ldots \ldots \ldots \ldots$ & .45 & .40 & & \\
\hline & Primula bulleyana $\ldots \ldots \ldots \ldots$ & .50 & & & \\
\hline & denticulata $\ldots \ldots \ldots \ldots \ldots$ & .50 & 45 & & \\
\hline & dent. cashmiriana ........ & .50 & 45 & & \\
\hline & florindae ............. & 50 & .45 & & \\
\hline & frondosa $\ldots \ldots \ldots \ldots \ldots$ & .50 & .45 & .40 & \\
\hline & longiflora $\ldots \ldots \ldots \ldots \ldots$ & .50 & & & \\
\hline & polyantha $\ldots \ldots \ldots \ldots \ldots$ & 35 & .30 & 25 & \\
\hline & vulgaris $\ldots \ldots \ldots \ldots$ & 40 & & & \\
\hline & Pulmonaria azurea $\ldots \ldots \ldots$ & 40 & & & \\
\hline & Rhexia virginica $\ldots \ldots \ldots \ldots \ldots$ & 40 & & & \\
\hline & Ruellia ciliosa ......... & .60 & .55 & & \\
\hline & Saxifraga aiz. emarginata ... & 1.00 & 90 & & \\
\hline & aiz. lagaveana ...... & 1.00 & $\ldots$ & & \\
\hline & aiz. rosea .... & 1.00 & .90 & & \\
\hline & andrewsi ........... & 1.00 & & & \\
\hline & cartiliginea ......... & 1.00 & 90 & & \\
\hline & cotyledon X longifolia . & 1.00 & .90 & & \\
\hline & macnabiana $\ldots \ldots \ldots$ & .75 & .70 & & \\
\hline & apiculata ... & 1.00 & $\cdots$ & & \\
\hline & umbrosa ... & .60 & .55 & & \\
\hline & sarmentosa $\ldots \ldots \ldots \ldots \ldots$ & .50 & .45 & .40 & \\
\hline
\end{tabular}


Amount carried over \$

\begin{tabular}{l|l|c|c|c|c|}
\hline Quan. & 5 & 10 & 100 & \\
\hline
\end{tabular}

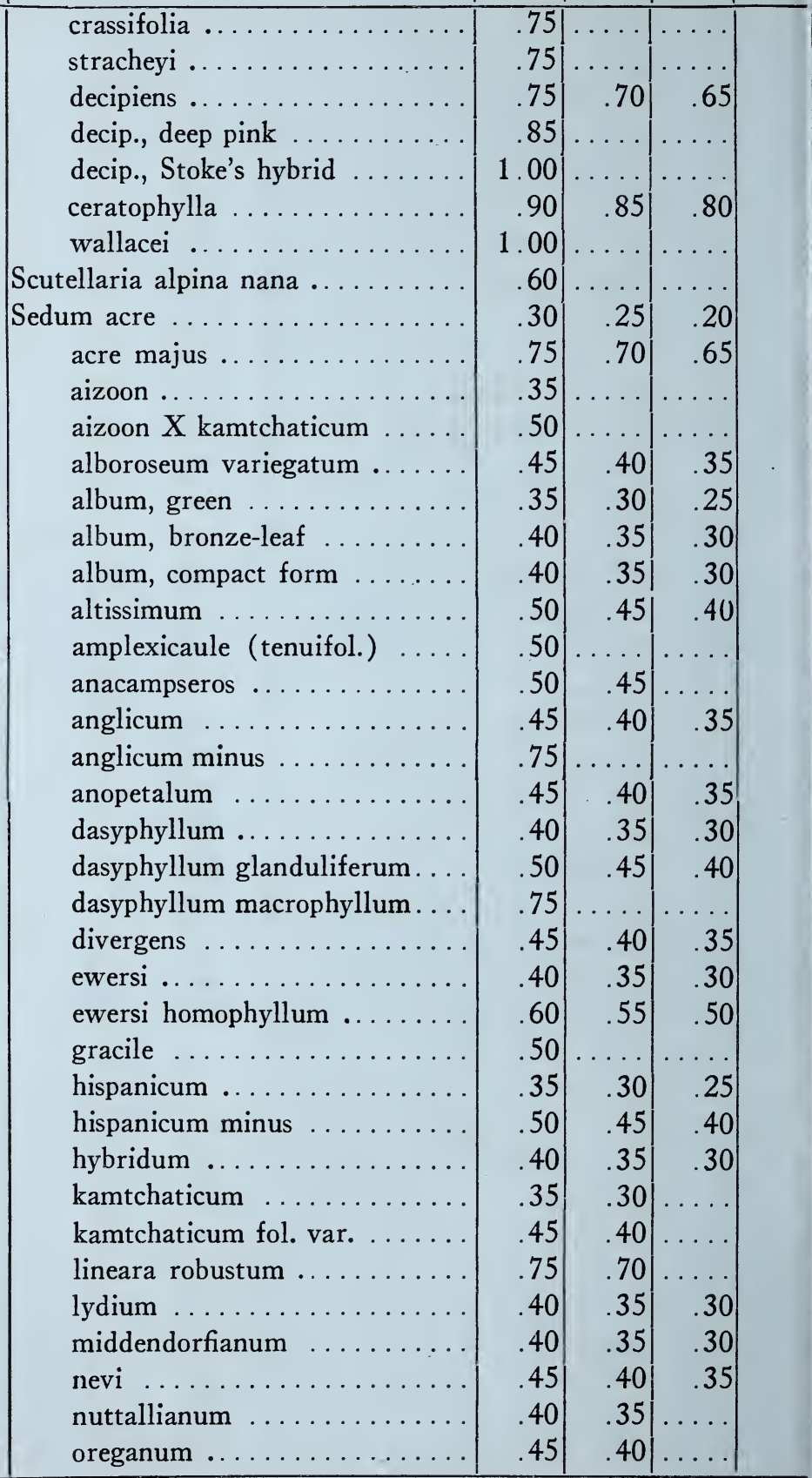

Total \$ 
Amount carried over \$

\begin{tabular}{|c|c|c|c|c|c|}
\hline Quan. & & $\begin{array}{c}5 \\
\text { Rate }\end{array}$ & $\begin{array}{c}10 \\
\text { Rate }\end{array}$ & $\begin{array}{c}100 \\
\text { Rate }\end{array}$ & Total \\
\hline & populifolium ...... & .75 & & & \\
\hline & pulchellum, perennial .... & .60 & & & \\
\hline & pülchellum, annual ...... & 45 & .40 & & \\
\hline & reflexum $\ldots \ldots \ldots \ldots$ & 40 & .35 & .30 & \\
\hline & reflexum cristatum $\ldots .$. & .50 & .45 & .40 & \\
\hline & rupestre, larger form ....... & .40 & .35 & .30 & \\
\hline & rupestre, smaller form ....... & .40 & .35 & .30 & \\
\hline & sarmentosum $\ldots \ldots \ldots \ldots$ & .35 & .30 & .25 & \\
\hline & sexangulare . & .35 & .30 & 25 & \\
\hline & sieboldi ............. & .40 & .35 & .30 & \\
\hline & sieboldi variegatum . . . . . & .75 & .70 & & \\
\hline & spectabile, dwarf form & .60 & .55 & & \\
\hline & spurium $\ldots \ldots \ldots \ldots \ldots$ & .35 & .30 & & \\
\hline & spurium album $\ldots \ldots \ldots \ldots$ & .40 & .35 & & \\
\hline & spurium coccineum (splendens) & .40 & .35 & 30 & \\
\hline & stenopetalum $\ldots \ldots \ldots \ldots$ & 45 & .40 & 35 & \\
\hline & stoloniferum $\ldots \ldots \ldots \ldots$ & .40 & .35 & . & \\
\hline & stribrnyi $\ldots \ldots \ldots \ldots \ldots$ & .60 & & & \\
\hline & ternatum $\ldots \ldots \ldots \ldots$ & .40 & .35 & .30 & \\
\hline & Sempervivum arachnoideum ... & 40 & .35 & .30 & \\
\hline & arenarium $\ldots \ldots \ldots$ & 40 & .35 & & \\
\hline & brauni ............. & .40 & .35 & & \\
\hline & calcareum ............ & .40 & .35 & & \\
\hline & fauconnetti ............ & .70 & .65 & .60 & \\
\hline & funcki $\ldots \ldots \ldots \ldots \ldots$ & .35 & .30 & .25 & \\
\hline & la harpei $\ldots \ldots \ldots \ldots$. & .45 & .40 & .35 & \\
\hline & mettenianum $\ldots \ldots \ldots$ & .45 & .40 & & \\
\hline & pittoni $\ldots \ldots \ldots \ldots \ldots$ & 45 & .40 & .35 & \\
\hline & regia amaliae $\ldots \ldots \ldots$ & .75 & & & \\
\hline & rubicundum $\ldots \ldots \ldots \ldots$ & 60 & .55 & .50 & \\
\hline & rubicundum hybridum ... & 60 & & & \\
\hline & seedling No. $60 \ldots \ldots$ & 60 & & & \\
\hline & soboliferum $\ldots \ldots \ldots$ & .35 & .30 & .25 & \\
\hline & soboliferum . . . . . & 35 & .30 & 25 & \\
\hline & tectorum .......... & 35 & .30 & 25 & \\
\hline & triste $\ldots \ldots$ & 50 & .45 & & \\
\hline & Senecio tyrolensis & 60 & & & \\
\hline & Silene alpestris . . & 45 & .40 & & \\
\hline & schaftae $\ldots \ldots \ldots$ & .35 & .30 & & \\
\hline & Symphyandra hoffmanni ......... & .50 & .45 & & \\
\hline
\end{tabular}


Amount carried over \$

\begin{tabular}{l|l|c|c|c|c}
\hline Quan. & 5 & 10 & 100 & \\
\hline
\end{tabular}

Teucrium chamaedrys .........

canadense

Thymus citriodorus aureo-var.

herba-barona

serpyllum

\begin{tabular}{l|l|l|}
.45 & .40 & .35 \\
\hline 50 &... &...
\end{tabular}

serpyllum album

.50

serpyllum aureo var.

.50

.60

.35

serpyllum, deep rose

serpyllum lanuginosus

.40

serpyllum, large-leaf form

.45

serpyllum, silver variegated

.50

vulgaris

Tsuga canadensis pendula, $2 \mathrm{I} / 2$ feet .

Umbilicus chrysanthus

.50

.40

$15.00 \quad 12.50$

Valeriana montana .

$.50 \quad .45$

Veronica allioni .

$.50 \quad .45$

$.45 \quad .40$

.40

armena

.50

filifolia

.50

filiformis

gentianoides

incana

nummularia

pectinata, rose

.45

pectinata, blue

repens

saxatyle

saxatyle alba

spicata corymbosa

.40

.35

.60

60

.60

$.40 \quad .35$

.35

.45

.40

.45

.40

.40

.35

teucrium rupestre

teucr. rupestre alba

$.50 \quad .45$

$.60 \quad .55$

$.50 \quad .45$

$.35 \quad .30$

$.45 \quad .40$

teucr. rup. rosea

.40

teucr. rup. trehani

Vinca alpina

herbacea

Viola odorata alba

odorata Princess of Wales

odorata Mrs. David Lloyd

George ...

Jersey Gem

.45

.45

.45

$\begin{array}{lll}40 & .35 & .30\end{array}$

rugulosa 
